\title{
Fluorescent biological aerosol particle concentrations and size distributions measured with an Ultraviolet Aerodynamic Particle Sizer (UV-APS) in Central Europe
}

\author{
J. A. Huffman ${ }^{1}$, B. Treutlein ${ }^{1,2}$, and U. Pöschl ${ }^{1}$ \\ ${ }^{1}$ Max Planck Institute for Chemistry, Biogeochemistry Department, Becherweg 27, Mainz, 55128, Germany \\ ${ }^{2}$ now at: Ludwig Maximilians University, Institute for Physical Chemistry, Munich, Germany
}

Received: 24 July 2009 - Published in Atmos. Chem. Phys. Discuss.: 28 August 2009

Revised: 5 March 2010 - Accepted: 16 March 2010 - Published: 6 April 2010

\begin{abstract}
Primary Biological Aerosol Particles (PBAPs), including bacteria, spores and pollen, are essential for the spread of organisms and disease in the biosphere, and numerous studies have suggested that they may be important for atmospheric processes, including the formation of clouds and precipitation. The atmospheric abundance and size distribution of PBAPs, however, are largely unknown. At a semi-urban site in Mainz, Germany we used an Ultraviolet Aerodynamic Particle Sizer (UV-APS) to measure Fluorescent Biological Aerosol Particles (FBAPs), which provide an estimate of viable bioaerosol particles and can be regarded as an approximate lower limit for the actual abundance of PBAPs. Fluorescence of non-biological aerosol components are likely to influence the measurement results obtained for fine particles $(<1 \mu \mathrm{m})$, but not for coarse particles $(1-20 \mu \mathrm{m})$.

Averaged over the four-month measurement period (August-December 2006), the mean number concentration of coarse FBAPs was $\sim 3 \times 10^{-2} \mathrm{~cm}^{-3}$, corresponding to $\sim 4 \%$ of total coarse particle number. The mean mass concentration of FBAPs was $\sim 1 \mu \mathrm{g} \mathrm{m}^{-3}$, corresponding to $\sim 20 \%$ of total coarse particle mass. The FBAP number size distributions exhibited alternating patterns with peaks at various diameters. A pronounced peak at $\sim 3 \mu \mathrm{m}$ was essentially always observed and can be described by the following campaign-average lognormal fit parameters: geometric mean diameter $3.2 \mu \mathrm{m}$, geometric standard deviation 1.3 , number concentration $1.6 \times 10^{-2} \mathrm{~cm}^{-3}$. This peak is likely due to
\end{abstract}

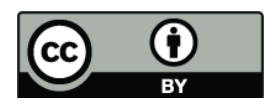

Correspondence to: J. A. Huffman (a.huffman@mpic.de) fungal spores or agglomerated bacteria, and it exhibited a pronounced diel cycle (24-h) with maximum intensity during early/mid-morning. FBAP peaks around $\sim 1.5 \mu \mathrm{m}, \sim 5 \mu \mathrm{m}$, and $\sim 13 \mu \mathrm{m}$ were also observed, but less pronounced and less frequent. These may be single bacterial cells, larger fungal spores, and pollen grains, respectively.

The observed number concentrations and characteristic sizes of FBAPs are consistent with microscopic, biological and chemical analyses of PBAPs in aerosol filter samples. To our knowledge, however, this is the first exploratory study reporting continuous online measurements of bioaerosol particles over several months and a range of characteristic size distribution patterns with a persistent bioaerosol peak at $\sim 3 \mu \mathrm{m}$. The measurement results confirm that PBAPs account for a substantial proportion of coarse aerosol particle number and mass in continental boundary layer air. Moreover, they suggest that the number concentration of viable bioparticles is dominated by fungal spores or agglomerated bacteria with aerodynamic diameters around $3 \mu \mathrm{m}$ rather than single bacterial cells with diameters around $1 \mu \mathrm{m}$.

\section{Introduction}

Biogenic aerosols are ubiquitous in the Earth's atmosphere and they play important roles in atmospheric chemical and physical processes, climate, biological systems, and public health (Cox and Wathes, 1995; Pöschl, 2005; Jaenicke et al., 2007). Primary Biological Aerosol Particles (PBAPs) are pieces of biological material emitted or suspended directly from the biosphere to the atmosphere. The main types

Published by Copernicus Publications on behalf of the European Geosciences Union. 
and characteristic size ranges of PBAP are viruses (0.01$0.3 \mu \mathrm{m})$, bacteria $(0.1-10 \mu \mathrm{m})$, fungal and fern spores $(1-$ $30 \mu \mathrm{m})$, plant pollen $(5-100 \mu \mathrm{m})$, and fragments of animal and plant matter (e.g. Gregory, 1978; Simoneit and Mazurek, 1982; Matthias-Maser and Jaenicke, 1995; Jones and Harrison, 2004; Jaenicke, 2005; Elbert et al., 2007; Bauer et al., 2008). PBAPs can play an important role in public health by affecting allergies (Linskens and Cresti, 2000; Franze et al., 2005 ) and spreading disease to humans and crops, both naturally and as agents of terrorism (e.g. Lacey and Dutkiewicz, 1994; Brown and Hovmoller, 2002; Ho and Duncan, 2005). Many organisms rely on bioaerosols for the distribution and transfer of genetic material for reproductive purposes, as in the cases of plant pollen and fungal spores, which can also undergo transport over long distances (Elbert et al., 2007, and referencse therein). PBAPs may also influence climate and the hydrological cycle by initiating the formation of clouds and precipitation as cloud condensation and ice nuclei (Dingle, 1966; Schnell and Vali, 1972; Hamilton and Lenton, 1998; Diehl et al., 2001; Lohmann and Feichter, 2005; Dusek et al., 2006; McFiggans et al., 2006; Sun and Ariya, 2006; Christner et al., 2008; Deguillaume et al., 2008; Morris et al., 2008; Mortazavi et al., 2008; Rosenfeld et al., 2008; Ariya et al., 2009; Bowers et al., 2009; Pratt et al., 2009; Prenni et al., 2009).

Recent studies have found significant concentrations of DNA $\left(\mathrm{ng} \mathrm{m}^{-3}\right)$ and a wide range of bacteria and fungal spores in fine and coarse particulate matter from urban, rural, and high-alpine air (Wittmaack et al., 2005; Després et al., 2007; Fröhlich-Nowoisky et al., 2009). For tropical rainforest regions where both physicochemical processes in the atmosphere and biological activity at the Earth's surface are particularly intense, Elbert et al. (2007) reported that fungal spores account for large fractions of coarse particle mass concentrations $(\sim 30 \%)$ and estimated global emission rates of the order of $50 \mathrm{Tg} \mathrm{a}^{-1}$. Jaenicke et al. (2007) summarize measurements covering a variety of geographical locations and particle size ranges showing that $15-74 \%$ of the total aerosol number as being PBAPs including $\sim 20 \%$ in the semiurban setting in Mainz, Germany. Continuous measurements of PBAPs have been limited, however, and so actual abundances, properties, as well as the origin of PBAPs and their components are still poorly quantified and understood. Recent model studies and literature reviews highlight the need for more measurement data to constrain regional and global emissions, transport, and abundance of PBAPs in the atmosphere (Burrows et al., 2009a, b; Heald and Spracklen, 2009).

In the past, most PBAP measurements were based on off-line techniques with low time resolution (hours/days). Within the last decades and motivated by need to detect bioaerosols as possible Bio-Warfare Agents (BWA), the application of ultraviolet Laser-Induced Fluorescence (LIF) to online aerosol analysis has enabled the detection of PBAPs in real-time, with time resolution of minutes or less (Hill et al.,
1995; Pinnick et al., 1995; Hairston et al., 1997; Cheng et al., 1999; Reyes et al., 1999; Seaver et al., 1999; Snyder et al., 2004; Kaye et al., 2005; Jonsson et al., 2006; Cabredo et al., 2007; Manninen et al., 2008; Pan et al., 2009; Sivaprakasam et al., 2009; Bundke et al., 2010). While each independently designed instrument has unique advantages (e.g. detection of full emission spectra or from multiple fluorescence excitation wavelengths), the Ultraviolet Aerodynamic Particle Sizer (UV-APS) was the first such instrument to be made commercially available and to utilize aerodynamic particle sizing. As a result, the UV-APS, also known as Fluorescent APS (FLAPS), has become available for the investigation of ambient biological aerosol and presents unique opportunities to inform atmospheric science, while other published research has focused largely on BWA detection. The UV-APS utilizes a pulsed excitation laser at $355 \mathrm{~nm}$ and detects emitted fluorescence in the region of $420-575 \mathrm{~nm}$ (Hairston et al., 1997; Brosseau et al., 2000). This set of fluorescence wavelengths enables the detection of reduced pyridine nucleotides (e.g. $\mathrm{NAD}(\mathrm{P}) \mathrm{H})$ and riboflavin, which are molecules linked to cellular metabolism and thus specific for living cells (Harrison and Chance, 1970; Eng et al., 1989; Kell et al., 1991; Li et al., 1991; Iwami et al., 2001; Hill et al., 2009). Accordingly, detection of auto-fluorescence under these conditions may indicate the presence of viable biological material in the aerosol particles (Setlow and Setlow, 1977; Hairston et al., 1997; Laflamme et al., 2005), though other biological molecules may also auto-fluoresce (e.g. chlorophyll, cellulose). Non-viable organic material such as nutrient broth and peptone water can also exhibit fluorescence in the operating wavelengths (Agranovski et al., 2003b). These substances are not likely to occur in the atmosphere, however, and if so they would most likely be of biological origin (albeit not viable) and thus qualify as components of PBAPs. A number of external factors, such as relative humidity and environmental stress have been found to influence the fluorescence of biological organisms, and the fluorescence signals of $\mathrm{NAD}(\mathrm{P}) \mathrm{H}$ can be affected by binding to proteins (Huber et al., 2000; Agranovski et al., 2003a). Further investigation will be required to achieve full understanding of the response of the UV-APS to different types of biogenic aerosol particles and to quantify potential interferences with non-biogenic particles and particle components (e.g. soot and polycyclic aromatic compounds, PAHs) that may also display fluorescence. As discussed below, such interferences may indeed influence the measurement results obtained for fine aerosol particles $(<1 \mu \mathrm{m})$. In the coarse fraction, certain components of mineral dust (e.g. kaolin) may exhibit weak fluorescence, but at significantly lower levels than most types of biological particles (Sivaprakasam et al., 2004). In experiments with test aerosols in an outdoor environment Ho et al. $(1999,2002)$ found that fluorescence signals from supermicron aerosols were dominated by viable PBAPs and found no indications that non-biological materials contributed to aerosol fluorescence at the wavelengths used. Indeed, all 
available information suggests that coarse fluorescent particles $(>1 \mu \mathrm{m})$ measured by the UV-APS can be regarded as "Fluorescent Biological Aerosol Particles" (FBAP), which provide an estimate of viable bioaerosol particles and whose abundance represents an approximate lower limit for the actual abundance of primary biological aerosol particles.

Previous work has studied the UV-APS response in the laboratory to cell viability (Agranovski et al., 2003a; Laflamme et al., 2005), aerosols containing marker biological molecules (Agranovski et al., 2004b; Agranovski and Ristovski, 2005), and also with respect to real-time measurement of bacteria (Brosseau et al., 2000; Agranovski et al., 2003a, b) and fungal spores (Kanaani et al., 2007, 2008a, b), but little has been done to utilize the instrument for long term (> days) ambient measurement. Ho and Spence (1998) used a UV-APS for short periods of time to measure background FBAP concentrations at several military locations within Canada, and both Pinnick et al. (2004) and Pan et al. (2007) utilized a LIF spectrometer for detection of FBAP in ambient air in New Mexico and Maryland. A variety of bioaerosol detection techniques have been utilized to characterize bioaerosol emissions from a variety of occupationally specific exposure environments, such as from livestock facilities (Agranovski et al., 2004a; Seedorf, 2004; Kim et al., 2007), waste treatment plants (Lavoie et al., 2006; Nikaeen et al., 2009) and in various indoor environments (Burge, 1990; Moschandreas et al., 1996; Law et al., 2001). Recently, fluorescence measurements of bioparticles have also been reported for tropical rainforest air (Gabey et al., 2009; Prenni et al., 2009; Huffman, Garland, Pöschl, et al., 2010).

In this study we have applied a UV-APS for the detection and sizing of FBAPs in urban and rural continental aerosols over a four-month period from 3 August-4 December 2006. To our knowledge, this represents the first multi-month ambient measurement study involving an instrument for realtime bioaerosol detection using auto-fluorescence and also the first in a semi-urban environment.

\section{Methods}

\subsection{UV-APS operating principles and conditions}

An ultraviolet aerodynamic particle sizer (UV-APS; TSI Inc. Model 3314, St. Paul, MN) was utilized for this study following standard, manual-advised procedures. A detailed description of the instrument has been given elsewhere (Hairston et al., 1997; Brosseau et al., 2000), and so only a brief introduction is given here. Aerodynamic particle sizing in the diameter range $\left(D_{\mathrm{a}}\right)$ of $0.54-19.81 \mu \mathrm{m}$ (geometric mid-point diameter) is performed in the instrument by measuring the time of flight between two red $(633 \mathrm{~nm}) \mathrm{He}-\mathrm{Ne}$ lasers. Fluorescence of individual aerosol particles in the wavelength range of $420-575 \mathrm{~nm}$ is measured after excitation by a third ultraviolet laser (Nd:YAG) at $355 \mathrm{~nm}$. The particle counting efficiency of the instrument drops below unity at $D_{\mathrm{a}}<0.7 \mu \mathrm{m}$ (counting efficiency $\sim 0.5$ at $0.54 \mu \mathrm{m}$ ), thus concentration values reported for particles $<0.7 \mu \mathrm{m}$ should be considered as lower limit values. The instrument manufacturer specifies the upper size limit of the UV-APS at $15 \mu \mathrm{m}$. Upon manufacturer calibration, however, polystyrene latex spheres (PSL, Duke Scientific) up to $20 \mu \mathrm{m}$, were properly sized by the UV-APS, though possibly with lower efficiency. As a result, particles detected between 15-20 $\mu \mathrm{m}$ are included in our analyses, but the reported concentration values should again be considered as lower limit values. Aerosol sampling was performed with a volumetric flow of $5 \mathrm{~L} \mathrm{~min}^{-1}(\mathrm{Lpm})$ at ambient pressure and temperature. Within the instrument, the total flow was split into an inner sample flow of $1.0 \pm 0.1 \mathrm{Lpm}$ passing through the nozzle and optical measurement cell and a sheath flow of $4.0 \pm 0.1 \mathrm{Lpm}$ (pressure difference feedback control). The flow rates were regularly checked with external flow meters (TSI Inc. Model 4140 Thermal Mass Flowmeter and Sensidyne Gilibrator-2). The inner and total volumetric flow rates stayed generally within the range of $1.0-1.1 \mathrm{Lpm}$ and $4.9-$ 5.0 Lpm, respectively.

The instrument was controlled and the measurement data were recorded with an external computer connected via RS232 ports using the manufacturer's Aerosol Instrument Manager software (TSI AIM). Aerodynamic diameter, side scatter intensity, and fluorescence intensity measurements were recorded, initiated every $5 \mathrm{~min}$ and integrated over a sample length of 299 s. Sample measurements were continuously repeated over a period of four months from 3 August to 4 December 2006 (122 days, 34270 data points) and only briefly interrupted for maintenance procedures (usually $<30 \mathrm{~min}$ per week for flow check and nozzle cleaning as detailed in the instrument manual). The Local Time (LT) used for data analysis and all times reported here refer to Central European Summer Time (CEST) from the beginning of the reported measurements in August until 29 October, and thereafter to Central European Time (CET).

\subsection{Measurement location and sampling}

The UV-APS instrument was operated in a laboratory on the third (top) floor of the Max Planck Institute for Chemistry ( $\sim 10 \mathrm{~m}$ above ground; eastward-facing location), which is located on the campus of the Johannes Gutenberg University in Mainz, Germany $\left(49^{\circ} 59^{\prime} 31.07^{\prime \prime} \mathrm{N}, 8^{\circ} 14^{\prime} 14.64^{\prime \prime} \mathrm{E}\right.$; $100 \mathrm{~m}$ a.s.l. - above sea level). Towards the north and east, the university campus is surrounded by the city of Mainz and adjacent urban areas in the Rhine-Main metropolitan region. Towards the south and west, the university campus is surrounded by farm, grass, and forested land with small villages and towns in a rural region extending over several hundred kilometres. Thus, air masses advected to the sampling location during this study can be considered as typical Central 
European mixtures of air from a metropolitan area and from a rural background region.

The UV-APS instrument was placed next to a window inside the laboratory, through which ambient air was sampled using electrically-conductive silicon rubber tubing (length $1.6 \mathrm{~m}$, inner diameter $12 \mathrm{~mm}$, sample flow residence time $\sim 2 \mathrm{~s}$ ). Flow through the tube was considered laminar at all times, and so diffusion losses are considered negligible for all sampled particle sizes. From the instrument inlet on top of the UV-APS the sampling tube was smoothly bent through the window to minimize particle losses due to impaction (curvature radius $\sim 1 \mathrm{~m}$ ). It is possible that the sampled air masses were influenced by dynamics involving the building structure, though no evidence of this was observed.

\subsection{Data processing and analysis}

Kanaani et al. (2007) reported that all viable bioaerosols ("with endogenous metabolites") they tested were recorded by the UV-APS as having fluorescence in channels 2 and above. Agranovski et al. (2004b), however, suggested that non-fluorescent background aerosols tested also exhibited fluorescence in channel 2. In the present study we calculated number size distributions of fluorescent aerosol particles, $\mathrm{d} N_{\mathrm{F}} / \mathrm{d} \log D_{\mathrm{a}}$, for each size bin from the sum of the particle number concentrations from fluorescence channels 3-64, and we calculated the total particle size distributions $\mathrm{d} N_{\mathrm{T}} / \mathrm{d} \log D_{\mathrm{a}}$, from channels 1-64. For comparison we also calculated $\mathrm{d} N_{\mathrm{F}} / \mathrm{d} \log D_{\mathrm{a}}$ using channels 2-64 as illustrated in supplemental Figs. S2-S4: http://www.atmos-chem-phys.net/10/ 3215/2010/acp-10-3215-2010-supplement.pdf. These show the enhancement of $\mathrm{d} N_{\mathrm{F}} / \mathrm{d} \log D_{\mathrm{a}}$ is strongly size dependent (Fig. S4), decreasing from a factor of 3.4 at $0.6 \mu \mathrm{m}$ to a factor of 1.1 at $20 \mu \mathrm{m}$. As a result, by excluding fluorescence channel 2 we expect to obtain a reasonable estimate and avoid over-counting the abundance of FBAPs, which in turn can be regarded as an approximate lower limit for the atmospheric abundance of PBAPs. Whether the fluorescent bioparticles are indeed viable is less well understood and needs to be further addressed as discussed below. The integrated number concentration of coarse fluorescent particles $\left(N_{\mathrm{F}, \mathrm{c}}>1 \mu \mathrm{m}\right)$ calculated by including fluorescence channel 2 is on average 1.5 times higher than the integrated $N_{\mathrm{F}, \mathrm{c}}$ excluding fluorescence channel 2 (Fig. S3a).

Some fraction of non-biological aerosol particles, including soot, PAHs, and cigarette smoke (Pan et al., 1999) exhibit fluorescence and could be erroneously counted as FBAPs by this technique. This is most likely to occur at small $(<1 \mu \mathrm{m})$ particle sizes where contribution from anthropogenic particles from combustion sources is dominant (Okada and Matsunum, 1974). If, for example, only a very small amount (e.g. $0.1 \%$ ) of a non-biological particle mode with peak of $100 \mathrm{~cm}^{-3}$ at $0.75 \mu \mathrm{m}$ exhibited fluorescence, a peak of $0.1 \mathrm{~cm}^{-3}$ would appear in the fluorescent particle number distribution. This peak may often be large enough to appear as a distinct peak in the distribution of fluorescent particles (Sect. 3.2). To investigate the contribution of non-biological particles that are counted by this technique (only considering fluorescence channels $>3$ ) the correlations between the integrated number concentrations of fluorescent particles $\left(N_{\mathrm{F}}\right)$ and total particles $\left(N_{\mathrm{T}}\right)$ were plotted separately for particles less than $1.0 \mu \mathrm{m}$ and greater than $1.0 \mu \mathrm{m}$ (Fig. S5). The correlation of the submicron particles is systematically linear $\left(R^{2}=0.51,34270\right.$ data points), with most outliers grouped as individual particle events, whereas the correlation of the supermicron particles is more random $\left(R^{2}=0.17\right)$. Supermicron primary biological particles are likely to have different sources and suspension mechanisms from the majority of the anthropogenic source-dominated submicron particles observed in this semi-urban location. As a result, correlation of $N_{\mathrm{F}}$ with $N_{\mathrm{T}}$ indicates that a large percentage of submicron particles exhibiting fluorescence may have anthropogenic sources, but this is not the case for supermicron particles. Similar correlations were also performed for smaller cut sizes. Goodness of fit values for these correlations increased with decreasing cut size, indicating an increasing influence of anthropogenic sources for submicron particles (e.g., Fig. S6 with $R^{2}=0.86$ for submicron particles $<0.723 \mathrm{~mm}$ ).

To avoid/minimize interference with non-biological fluorescent particles and for simplicity, therefore, we focus our analysis here on coarse particles $(>1 \mu \mathrm{m})$, and we exclude fine particles $(<1 \mu \mathrm{m})$ from the discussion of integral number concentrations. Accordingly, we take the integral number concentration of fluorescent particles larger than $1 \mu \mathrm{m}, N_{\mathrm{F}, \mathrm{c}}$, as the concentration of coarse FBAP. Similarly, $N_{\mathrm{T}, \mathrm{c}}$ refers to the total integral number concentration of particles detected by the UV-APS larger than $1 \mu \mathrm{m}$. Particle mass size distributions $\left(\mathrm{d} M / \mathrm{d} \log D_{\mathrm{a}}\right)$ were calculated for each size channel by multiplication of $\mathrm{d} N / \mathrm{d} \log D_{\mathrm{a}}$ with the volume of an aerodynamically equivalent sphere with the geometric midpoint diameter $\left(D_{\mathrm{a}, \mathrm{g}}\right)$ assuming a density of $1 \mathrm{~g} \mathrm{~cm}^{-3}$ and a shape factor of 1. Integral mass concentrations of coarse FBAPs $\left(M_{\mathrm{F}, \mathrm{c}}\right)$ and total coarse particles $\left(M_{\mathrm{T}, \mathrm{c}}\right)$ were also calculated by integration of particle mass $>1 \mu \mathrm{m}$, though these should be taken as a first approximation as a result of unknown particle density and shape. Comparison of UV-APS measurements with filters analyzed with SEM-EDX from Amazonia show similar trends in PBAP size distribution as well as in number and mass concentration, suggesting that, under certain conditions, the UV-APS FBAP measurement has no significant bias with respect to PBAP (Pöschl, Sinha, Martin, et al., 2010).

By plotting UV-APS diagnostic parameters after the measurement study was over, a correlation between logged Instrument Temperature (IT) and several instrument parameters (UV laser Power - UVP, Red Laser Current- RLC) was detected. Over the course of the 4-month measurement period, $R^{2}$ values for the correlations were 0.12 for IT-UVP and 

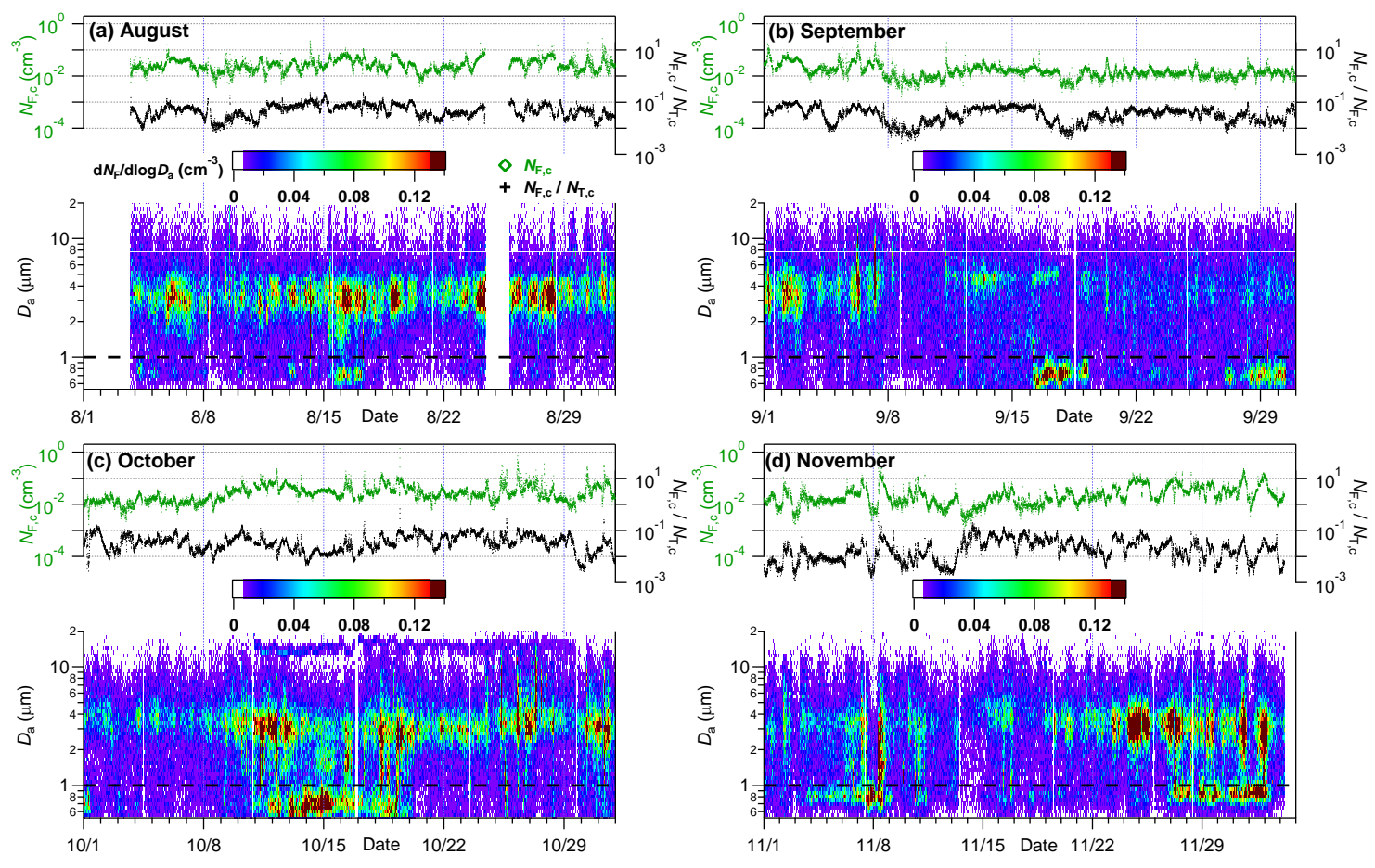

Fig. 1. Time series of fluorescent biological aerosol particle concentrations. Panel upper left: Integrated total coarse FBAP number $\left(N_{\mathrm{F}, \mathrm{c}}\right)$, green markers. Panel upper right: Number ratio of integrated coarse FBAP to TAP $\left(N_{\mathrm{F}, \mathrm{c}} / N_{\mathrm{T}, \mathrm{c}}\right)$, black markers. Panel lower half: Sizeresolved measurements $\left(\mathrm{d} N_{\mathrm{F}} / \mathrm{d} \log D_{\mathrm{a}}\right)$ for each 5-min sample over entire measurement period: (a) August, (b) September, (c) October, and (d) November (extending to 4 December).

0.78 for IT-RLC. Correlations between FBAP concentration and each of these parameters were also observed, but very weak $\left(R^{2}=0.0004,0.07\right.$, and 0.004 for IT, UVP, and RLC, respectively). We, therefore, suggest that it is important to monitor and consider these parameters for UV-APS operation and comparison of measurement data from different campaigns and instruments. It is possible that the absolute value of the FBAP signals could be affected by such instrumental parameters under certain conditions, but size distributions, trends and the main conclusions of this study are unlikely to be affected.

For the interpretation and scaling of size distribution data and plots (Sect. 3.2) we have calculated the limit of detection for concentrations measurable in each size channel of the UV-APS. These results are shown in the SOM.

\section{Results and discussion}

\subsection{Particle number and mass concentrations}

\subsubsection{Overview of number concentrations}

To our knowledge, no other time series of bioaerosol measurements with such high time and size resolution extending over a similarly long period have been reported previously. Thus, we first outline characteristic features of the time series
(Figs. 1, S7) in a general way to help the reader gain an overview of the observed concentration levels, trends, and variability before moving on to a more formal statistical treatment of the data (Fig. 2) and more detailed size-resolved analysis. Figure 1 shows time series of FBAP number concentrations and size distributions measured with the UV-APS for each month of the study.

Through-out the measurement period the total coarse particle number concentration, $N_{\mathrm{T}, \mathrm{c}}$ exhibited highly variable large spikes and strong diel (24-h) and day-to-day variations. Background concentrations consistently dropped to $<0.4 \mathrm{~cm}^{-3}$ between morning peaks during most of the campaign, and the highest total particle number concentrations were observed in November, with daily peaks above $8 \mathrm{~cm}^{-3}$. In contrast to total particles, the FBAP number concentration, $N_{\mathrm{F}, \mathrm{c}}$, exhibited less pronounced spikes and showed more consistent diel and day-to-day behavior. The highest $N_{\mathrm{F}, \mathrm{c}}$ concentrations were observed in late October, with maxima up to $0.85 \mathrm{~cm}^{-3}$. The relative contribution of FBAP to TAP number, $N_{\mathrm{F}, \mathrm{c}} / N_{\mathrm{T}, \mathrm{c}}$ showed similar temporal behaviour to $N_{\mathrm{F}, \mathrm{c}}$, but with more pronounced extremes due to the variability of the total number of coarse particles. In general, $N_{\mathrm{T}, \mathrm{c}}$ and $N_{\mathrm{F}, \mathrm{c}} / N_{\mathrm{T}, \mathrm{c}}$ were inversely correlated, but with relatively high scatter: as $N_{\mathrm{T}, \mathrm{c}}$ increases, $N_{\mathrm{F}, \mathrm{c}} / N_{\mathrm{T}, \mathrm{c}}$ decreases. More detailed trends are discussed in the SOM, and shown in Figs. S8-S9. 

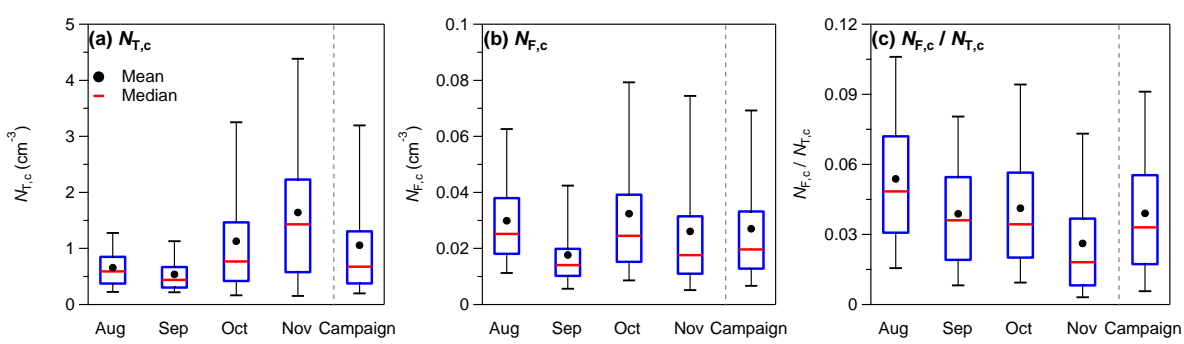

Fig. 2. Statistical distribution of integrated coarse TAP and FBAP number concentrations $(1-20 \mu \mathrm{m})$ measured during each month (AugustNovember) and over the full campaign as box-whisker plots. Black dot represents arithmetic mean, red bar represents median (50th percentile), lower and upper limits of blue box represent 25th and 75th percentiles, respectively. Horizontal bars at the end of lower and upper vertical bars represent 5 th and 95th percentiles, respectively. (a) $N_{\mathrm{T}, \mathrm{c}}$, (b) $N_{\mathrm{F}, \mathrm{c}}$, (c) $N_{\mathrm{F}, \mathrm{c}} / N_{\mathrm{T}, \mathrm{c}}$.
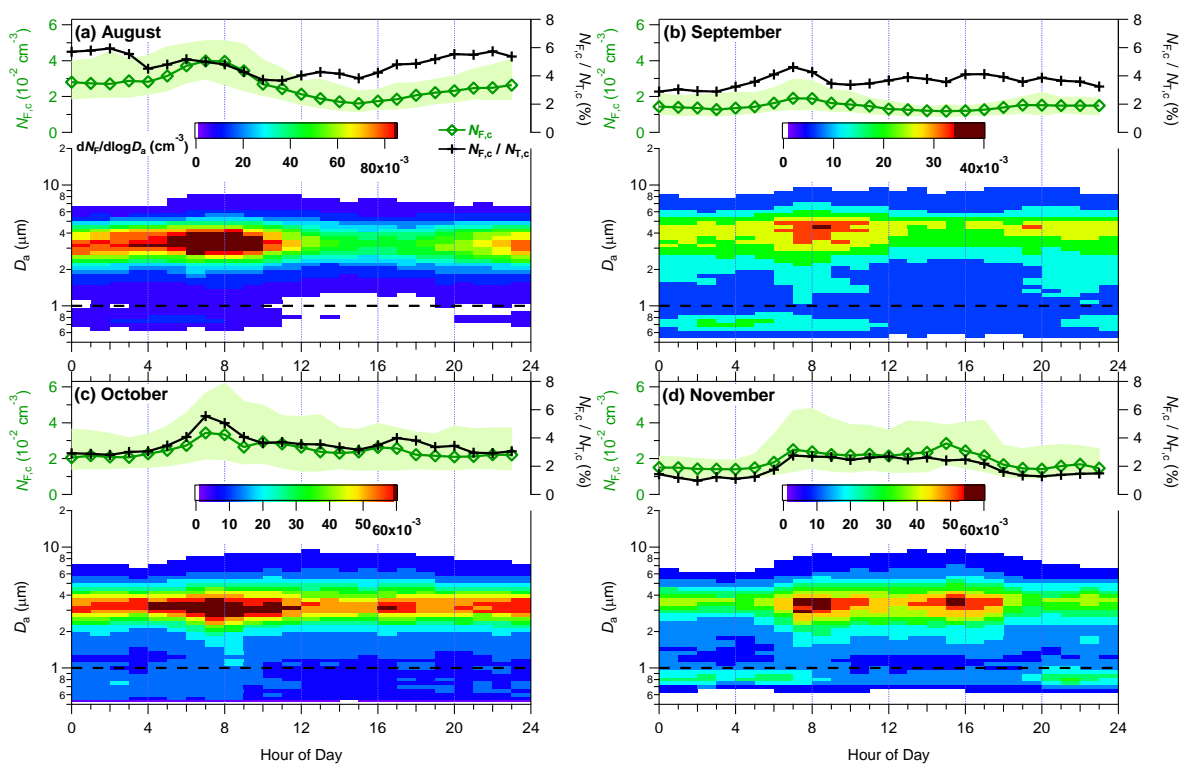

Fig. 3. Diel cycles of FBAP number concentrations and size distributions for each month of the measurement period (hourly median values vs. local time of day). Panel top halves: Integrated coarse FBAP concentration $\left(1-20 \mu \mathrm{m}, N_{\mathrm{F}, \mathrm{c}}\right)$ on left axis (green) and FBAP fraction of TAP number $\left(N_{\mathrm{F}, \mathrm{c}} / N_{\mathrm{T}, \mathrm{c}}\right)$ on right axis (black). Panel bottom halves: FBAP size distribution with hour of day on x-axis, aerodynamic diameter on $\mathrm{y}$-axis and color scale of $\mathrm{d} N_{\mathrm{F}} / \mathrm{d} \log D_{\mathrm{a}}$ with white values set to $<0.001 \mathrm{~cm}^{-3}$ for visual clarity. Dashed black line at $1.0 \mu \mathrm{m}$ shows particle size cut-off below which fluorescent particles were not considered FBAP due to interference with non-biological aerosol. Light-green shaded area shows FBAP concentration variability as the area between 25th-75th percentile traces. (a) August, (b) September, (c) October, and (d) November.

Statistical distributions of five-minute number concentration measurements over the course of the campaign are shown in Fig. 2 and tabulated in Table 1. The monthly mean of $N_{\mathrm{T}, \mathrm{c}}$ varied by a factor of $\sim 3$ over the course of the measurement period, from a minimum in September to a maximum in November. The months of October and November showed not only higher mean $N_{\mathrm{T}, \mathrm{c}}$ values, but also higher relative variability, reflected in the size of the 5-95th percentile bars in Fig. 2. The mean values of $N_{\mathrm{F}, \mathrm{c}}$ showed more consistency, however. September's low $N_{\mathrm{F}, \mathrm{c}}\left(0.018 \mathrm{~cm}^{-3}\right)$ was the only monthly mean value outside the relatively narrow mean range of $0.026-0.032 \mathrm{~cm}^{-3}$.
Diel trends over the four-month measurement period were also analyzed. Figure 3 shows the median FBAP value for each hour of the day for each of the four individual months of the measurement period, and Fig. S10 shows the campaign average. This shows clear evidence of a consistent trend of a relatively featureless background with a daily mid-morning peak at $\sim 3 \mu \mathrm{m}$. As the measurement proceeded later into the season, however, the morning peak shifted slightly later ( $\sim$ 06:00 in August- 08:00 in December) and a second diel mode appeared and shifted earlier in the day from September through the end of the study. Size distributions of FBAPs for selected periods will be discussed in detail in Sect. 3.2. 
Table 1. Integrated number concentrations (a) and mass concentrations (b) of coarse TAP and FBAP $(1-20 \mu \mathrm{m})$ : arithmetic mean and median for each month (August-November) and for the entire measurement campaign (3 August-4 December 2006).

\begin{tabular}{llrrrrr}
\hline Number & & Aug & Sep & Oct & Nov & Campaign \\
\hline$N_{\mathrm{T}, \mathrm{c}}\left(\mathrm{cm}^{-3}\right)$ & Mean & 0.65 & 0.54 & 1.13 & 1.64 & 1.05 \\
& Median & 0.58 & .044 & 0.77 & 1.43 & 0.67 \\
$N_{\mathrm{F}, \mathrm{c}}\left(\mathrm{cm}^{-3}\right)$ & Mean & 0.030 & 0.018 & 0.032 & 0.026 & 0.027 \\
& Median & 0.025 & 0.014 & 0.024 & 0.018 & 0.020 \\
$N_{\mathrm{F}, \mathrm{c}} / N_{\mathrm{T}, \mathrm{c}}(\%)$ & Mean & 5.36 & 3.89 & 4.12 & 2.61 & 3.90 \\
& Median & 4.81 & 3.60 & 3.43 & 1.81 & 3.30 \\
\hline Mass & & Aug & Sep & Oct & Nov & Campaign \\
\hline$M_{\mathrm{T}, \mathrm{c}}\left(\mu \mathrm{g} \mathrm{m}^{-3}\right)$ & Mean & 5.32 & 6.07 & 8.63 & 8.17 & 7.30 \\
& Median & 4.56 & 4.83 & 6.36 & 7.33 & 5.62 \\
$M_{\mathrm{F}, \mathrm{c}}\left(\mu \mathrm{g} \mathrm{m}^{-3}\right)$ & Mean & 1.03 & 1.09 & 1.94 & 0.92 & 1.26 \\
& Median & 0.80 & 0.80 & 1.40 & 0.64 & 0.86 \\
$M_{\mathrm{F}, \mathrm{c}} / M_{\mathrm{T}, \mathrm{c}}(\%)$ & Mean & 20.9 & 19.3 & 24.5 & 14.4 & 19.5 \\
& Median & 19.9 & 18.8 & 23.2 & 12.1 & 18.5 \\
\hline & & & & & &
\end{tabular}

Diel patterns of $N_{\mathrm{T}, \mathrm{c}}$ are very distinct from those of $N_{\mathrm{F}, \mathrm{c}}$ (supplemental Figs. S11-S12). The size-resolved $\mathrm{d} N_{\mathrm{T}} / \mathrm{d} \log D_{\mathrm{a}}$ over the four months of measurement consistently shows a dominant peak at $<1.0 \mu \mathrm{m}$ during night-time hours. The diel cycles of TAPs in (semi-) urban environments are usually governed by boundary layer mixing effects and anthropogenic emissions (Garland et al., 2008, 2009). This may explain the strong early morning (04:00) TAP peak in August that gradually shifts later in the morning and becomes less distinct. The diel cycles of FBAPs, however, are clearly different from those of TAP sources, and variability of FBAP sources seems to dominate over boundary layer mixing effects. Steep increase in FBAP concentrations observed in the morning after sunrise may suggest that a combination of high relative humidity and sunlight enhances the emission from bioaerosol sources (Elbert et al., 2007). Correlations of meteorological parameters with TAP and FBAP were performed and show a qualitative increase in $N_{\mathrm{F}, \mathrm{c}}$ with relative humidity, but with variable time offset and low correlation coefficient. No statistically significant correlation was found with wind direction. Further statistical analysis will be performed in follow-up studies, but are beyond the scope of this work.

Overall, the results show that FBAPs account for a small but significant fraction (typically $\sim 3-4 \%$, at most $\sim 15 \%$ ) of total coarse aerosol particle number in the investigated size range $(1-20 \mu \mathrm{m})$, and they indicate that the sources and sinks of FBAPs are less variable than those of other types of aerosol particles in Central Europe. These findings support earlier suggestions that bioaerosols may be regarded as the natural background aerosol over vegetated continental regions (Jaenicke, 2005; Andreae, 2007; Jaenicke et al., 2007; Andreae and Rosenfeld, 2008; Martin et al., 2009).

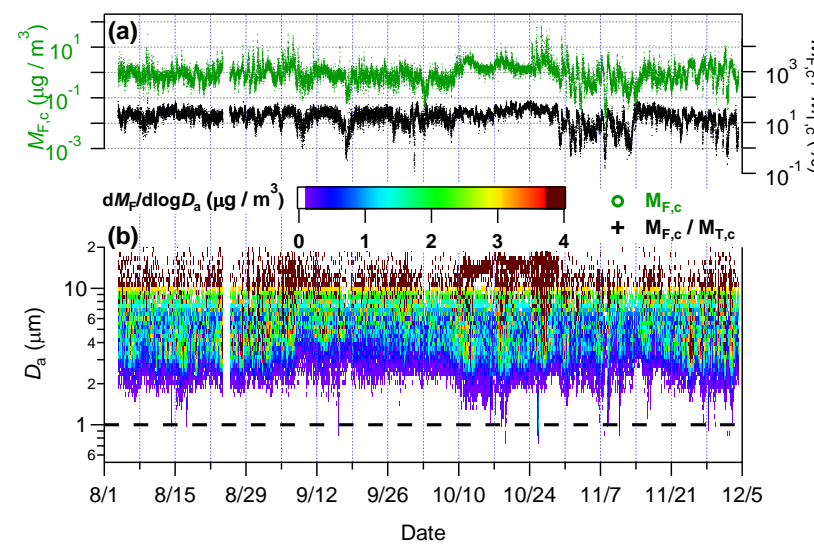

Fig. 4. Time series of FBAP mass concentrations and size distributions for the entire measurement period. (a) Integrated coarse FBAP mass concentration (1-20 $\left.\mu \mathrm{m}, M_{\mathrm{F}, \mathrm{c}}\right)$ on left axis (green) and FBAP fraction of TAP mass $\left(M_{\mathrm{F}, \mathrm{c}} / M_{\mathrm{T}, \mathrm{c}}\right)$ on right axis (black). Note that axes are logarithmically scaled and off-set from one another. Each data point represents a five-minute measurement. (b) FBAP size distribution with date on $\mathrm{x}$-axis, aerodynamic diameter on $\mathrm{y}$-axis, and color scale of $\mathrm{d} M_{\mathrm{F}} / \mathrm{d} \log D_{\mathrm{a}}$ with white values set to $0.1 \mu \mathrm{g} \mathrm{m} \mathrm{m}^{-3}$ for visual clarity. Dashed black line at $1.0 \mu \mathrm{m}$ shows particle size cut-off below which fluorescent particles were not considered FBAP due to interference with non-biological aerosol.

\subsubsection{Overview of mass concentrations}

Though the UV-APS fundamentally measures particle number, the average mass of size-resolved particles can be estimated as a first approximation by assuming unit density. Accordingly, we present here an overview of the estimated FBAP mass concentration over the course of the measurement period. Figure 4 shows the integrated total coarse particle mass $\left(M_{\mathrm{F}, \mathrm{c}}\right)$, the fraction of integrated FBAP mass to TAP mass $\left(M_{\mathrm{F}, \mathrm{c}} / M_{\mathrm{T}, \mathrm{c}}\right)$, as well as a time series of sizeresolved measurements $\left(\mathrm{d} M_{\mathrm{F}} / \mathrm{d} \log D_{\mathrm{a}}\right)$. Figures similar to Fig. 4, each with a range of one month are shown in supplemental Fig. S13 in order to view temporal trends with more precision.

$M_{\mathrm{T}, \mathrm{c}}$ (Figs. S14-S15) exhibited a pattern of large fluctuations and frequent (several times per week) large peaks $\left(>25 \mu \mathrm{g} \mathrm{m}^{-3}\right)$ on top of a relatively clean background of between $1-4 \mu \mathrm{g} \mathrm{m}^{-3}$. $M_{\mathrm{F}, \mathrm{c}}$ varied at constant background of $0.51-1.49 \mu \mathrm{g} \mathrm{m}^{-3}$ (25-75th percentiles), also with frequent spikes in concentration. The highest background of $M_{\mathrm{F}, \mathrm{c}}$ rose 9-28 October when levels rarely dropped below $0.8 \mu \mathrm{g} \mathrm{m}^{-3}$ and peaked $>40 \mu \mathrm{g} \mathrm{m}^{-3}$ at least daily from $25-$ 27 October. Temporal trends in $M_{\mathrm{F}, \mathrm{c}}$ are only poorly reflected in $M_{\mathrm{F}, \mathrm{c}} / M_{\mathrm{T}, \mathrm{c}}$, as the ratio is qualitatively dominated by $M_{\mathrm{T}, \mathrm{c}} \cdot M_{\mathrm{F}, \mathrm{c}} / M_{\mathrm{T}, \mathrm{c}}$ varied within a range of $11-27 \% \mu \mathrm{g} \mathrm{m} \mathrm{m}^{-3}$ (25-75th percentiles) over the course of the measurements. Events with very high FBAP mass fractions above $65 \%$ occurred at least once a month (peaking at $92 \%$ on 9 August). 

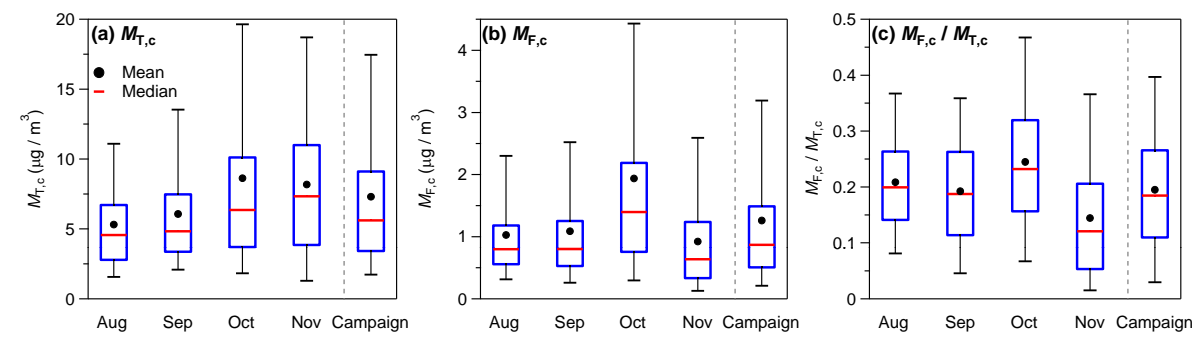

Fig. 5. Statistical distribution of integrated coarse TAP and FBAP mass concentrations (1-20 $\mu \mathrm{m})$ measured during each month (Aug-Nov) and over the full campaign as box-whisker plots (plots analogous to Fig. 2): (a) $M_{\mathrm{T}, \mathrm{c}}$, (b) $M_{\mathrm{F}, \mathrm{c}}$, (c) $M_{\mathrm{F}, \mathrm{c}} / M_{\mathrm{T}, \mathrm{c}}$.

Statistical distributions of five-minute mass concentration measurements over the course of the campaign are shown in Fig. 5 and tabulated in Table 1. The monthly mean values of $M_{\mathrm{T}, \mathrm{c}}$ exhibited lower relative variability, but similar temporal trends as $N_{\mathrm{T}, \mathrm{c}}$, with a general increase through the course of the measurement months. The monthly mean values of $M_{\mathrm{F}, \mathrm{c}}$ showed similar relative variability as $M_{\mathrm{T}, \mathrm{c}}$ and $N_{\mathrm{F}, \mathrm{c}}$, except in October when both mean $M_{\mathrm{F}, \mathrm{c}}$ values and relative variability were significantly higher. Similar to the trend in $N_{\mathrm{F}, \mathrm{c}} / N_{\mathrm{T}, \mathrm{c}}, M_{\mathrm{F}, \mathrm{c}} / M_{\mathrm{T}, \mathrm{c}}$ shows a gradual decrease over the course of the four months measured, with high $M_{\mathrm{F}, \mathrm{c}}$ in October causing the only outlier. The mean values are only marginally higher than the median values for $M_{\mathrm{F}, \mathrm{c}} / M_{\mathrm{T}, \mathrm{c}}$, indicating relatively low temporal variability. The median and mean for $M_{\mathrm{F}, \mathrm{c}} / M_{\mathrm{T}, \mathrm{c}}$ over the course of the campaign were 18.5 and $19.5 \%$, respectively. On average, the relative contribution of FBAP to TAP coarse particle mass was $\sim 5$ times larger than its contribution to coarse particle number $(\sim 3.9 \%)$. This is consistent with the observation that FBAPs show enhanced prevalence among large aerosol particles $(3-10 \mu \mathrm{m})$, as shown and discussed in Sect. 3.2.

Diel trends in $M_{\mathrm{F}, \mathrm{c}}$ were also analyzed and are shown in Fig. 6 for the entire campaign and in supplemental Fig. S16 for each individual month. Figure 6 shows that the lowest $M_{\mathrm{F}, \mathrm{c}}$ values occurred at night, with a temporally broad increase in $M_{\mathrm{F}, \mathrm{c}}$ from $\sim 05: 00-14: 00$ and a maximum at 08:00 $\left(1.17 \mu \mathrm{g} \mathrm{m}^{-3}\right)$. The overall trend of night-time lows with peak in mid-morning is similar to diel $N_{\mathrm{F}, \mathrm{c}}$ trend, but $M_{\mathrm{F}, \mathrm{c}}$ shows a greater relative increase from diel minimum to maximum compared with $N_{\mathrm{F}, \mathrm{c}}(66 \%$ and $79 \%$, respectively), and the morning $M_{\mathrm{F}, \mathrm{c}}$ peak is temporally broader and extends later in the day. $M_{\mathrm{F}, \mathrm{c}} / M_{\mathrm{T}, \mathrm{c}}$ exhibited a temporal trend similar to $M_{\mathrm{F}, \mathrm{c}}$, but less pronounced and showed relatively minor diel variability (minimum $14.7 \%$, maximum $20.5 \%$ ). The size-resolved diel trend of $M_{\mathrm{F}} / \mathrm{d} \log D_{\mathrm{a}}$ was also similar to $N_{\mathrm{F}} / \mathrm{d} \log D_{\mathrm{a}}$ in that a mid-morning peak of intermediate size $(\sim 5 \mu \mathrm{m}$ for particle mass distribution) heavily influences the trend in overall integrated coarse particle mass. Though relatively few in particle number, particles between 7-9 $\mu \mathrm{m}$ are consistent through day-light hours ( 07:00-17:00), however, and are the largest contributors to $M_{\mathrm{F}, \mathrm{c}}$ at those times. As was also the case for $N_{\mathrm{F}} / \mathrm{d} \log D_{\mathrm{a}}$,

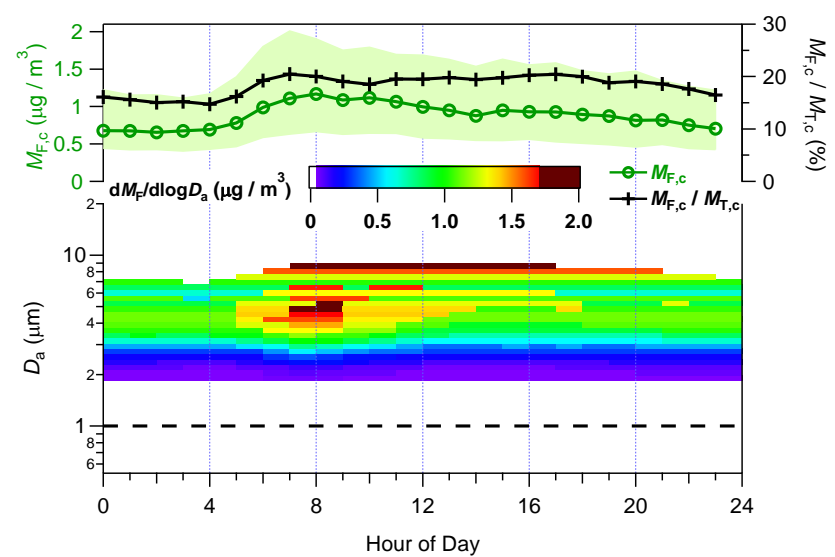

Fig. 6. Diel cycles of FBAP mass concentrations and size distributions for the entire measurement period (hourly median values vs. local time of day). (a) Integrated coarse FBAP concentration (1$20 \mu \mathrm{m}, M_{\mathrm{F}, \mathrm{c}}$ ) on left axis (green) and FBAP fraction of TAP mass $\left(M_{\mathrm{F}, \mathrm{c}} / M_{\mathrm{T}, \mathrm{c}}\right)$ on right axis (black). (b) FBAP mass size distribution with hour of day on $\mathrm{x}$-axis, aerodynamic diameter on y-axis, and color scale of $\mathrm{d} M_{\mathrm{F}} / \mathrm{d} \log D_{\mathrm{a}}$ with white values set to $0.04 \mu \mathrm{g} \mathrm{m}^{-3}$ for visual clarity. Dashed black line at $1.0 \mu \mathrm{m}$ shows particle size cutoff below which particles were not considered FBAP due to interference with non-biological aerosol. Light-green shaded area shows FBAP concentration variability as the area between 25 th-75th percentile traces. Sharp cut-off in mass concentration above $10.5 \mu \mathrm{m}$ is due to counting statistics and use of median values in this plot (i.e., above this size more than $50 \%$ of $5 \mathrm{~L}$ sample volumes contained no FBAP).

an afternoon peak of intermediate particle diameter became more apparent as each month progressed. During all periods of investigation particles smaller than $3 \mu \mathrm{m}$, though often important in number, were negligible in terms of particle mass. 

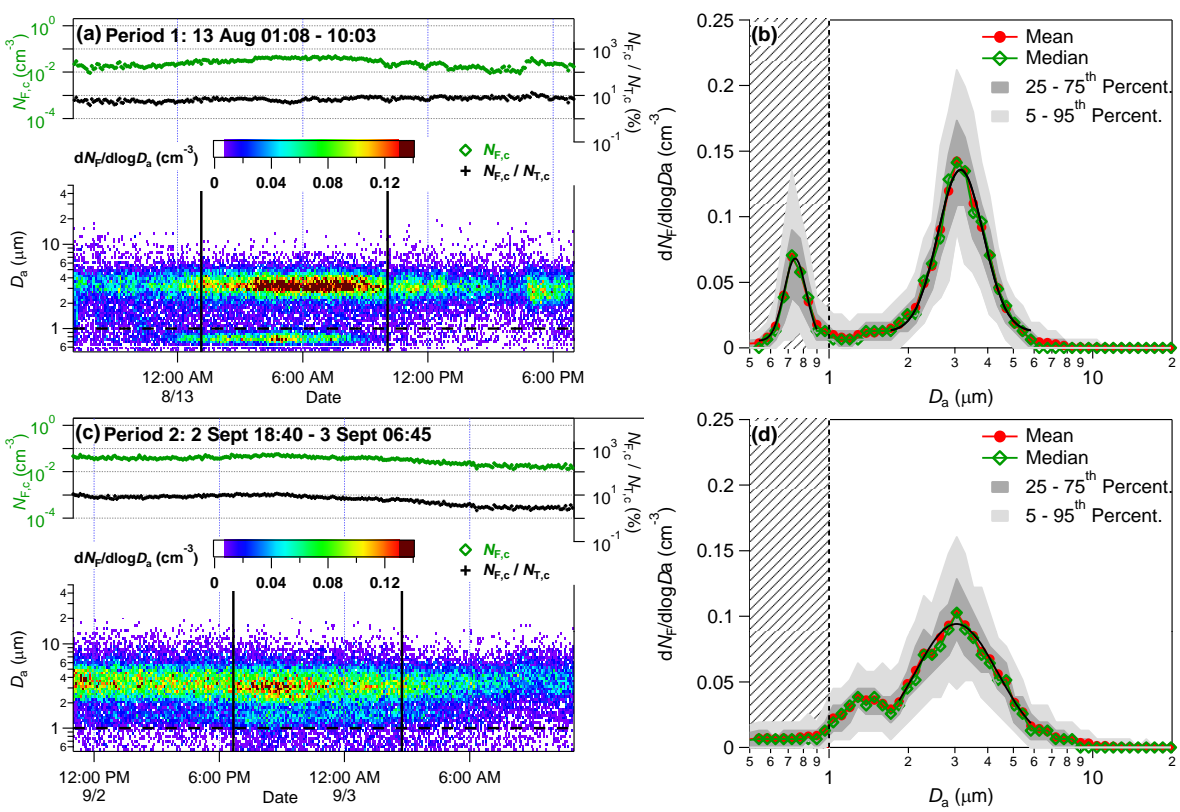

Fig. 7. Characteristic FBAP number size distribution patterns observed during exemplary periods \#1 and \#2. Left panels show time series of $N_{\mathrm{F}, \mathrm{c}}, N_{\mathrm{F}, \mathrm{c}} / N_{\mathrm{T}, \mathrm{c}}$ ratio and $\mathrm{d} N_{\mathrm{F}} / \mathrm{d} \log D$ on days of interest (analogous to Fig. 1), and black vertical lines indicate time periods over which exemplary size distributions were averaged $\left(\mathrm{d} N_{\mathrm{F}} / \mathrm{d} \log D_{\mathrm{a}}\right.$ vs. $D_{\mathrm{a}}$, right panels). Red traces represent mean values, green traces represent median values, dark gray regions show 25-75th percentile range, and light gray regions show 5-95th percentile range. Hatched area below $1.0 \mu \mathrm{m}$ indicates particle size range where fluorescent particles were not considered FBAP due to interference with non-biological aerosol. Black traces are lognormal fits to individual peaks (mean values) with the following fit parameters: (a)-(b) Period \#1; Fit 1.1: $D_{\mathrm{a}}=0.54-0.90 \mu \mathrm{m}, D_{\mathrm{a}, \mathrm{g}}=0.74 \mu \mathrm{m}, \sigma_{\mathrm{g}}=1.10, N=6.5 \times 10^{-3} \mathrm{~cm}^{-3} ;$ Fit $1.2: D_{\mathrm{a}}=1.7-5.8 \mu \mathrm{m} ; D_{\mathrm{a}, \mathrm{g}}=3.2 \mu \mathrm{m}, \sigma_{\mathrm{g}}=1.22, N=2.7 \times 10^{-2} \mathrm{~cm}^{-3}$; (c)-(d) Period \#2; Fit 2.1: $D_{\mathrm{a}}=1.8-5.8 \mu \mathrm{m} ; D_{\mathrm{a}, \mathrm{g}}=3.0 \mu \mathrm{m}, \sigma_{\mathrm{g}}=1.43, N=3.7 \times 10^{-2} \mathrm{~cm}^{-3}$.

\subsection{Size-distributions of particle number and mass}

\subsubsection{Exemplary particle size distributions}

Figure 1 shows that FBAPs with $D_{\mathrm{a}} \approx 3 \mu \mathrm{m}$ were nearly ubiquitous during the campaign. The FBAP peak at $\sim 3 \mu \mathrm{m}$ exhibits a clear diel cycle (Fig. 3), but rarely disappears completely. In addition to this peak, a variety of other FBAP peaks were frequently observed for varying lengths of time. Out of a wide range of different patterns and peaks in $\mathrm{d} N_{\mathrm{F}} / \mathrm{d} \log D_{\mathrm{a}}$ observed during the campaign, four characteristic modes of FBAP were most commonly found and clearly distinguishable. The peak diameters of these modes were typically around $\sim 1.5 \mu \mathrm{m}, \sim 3 \mu \mathrm{m}, \sim 5 \mu \mathrm{m}, \sim 13 \mu \mathrm{m}$, respectively. In the following section we highlight exemplary periods and size distributions illustrating characteristic features and the variability of the most commonly observed patterns and peaks in $\mathrm{d} N_{\mathrm{F}} / \mathrm{d} \log D_{\mathrm{a}}$.

Figure 7a-b (exemplary period \#1) illustrate the most frequently observed individual peaks in the $\mathrm{d} N_{\mathrm{F}} / \mathrm{d} \log D_{\mathrm{a}}$ distribution, with maxima at $3 \mu \mathrm{m}$ and $0.7 \mu \mathrm{m}$. As discussed in Sect. 2.3, the submicron peak in $\mathrm{d} N_{\mathrm{F}} / \mathrm{d} \log D_{\mathrm{a}}$ is likely due to fluorescent particle components from anthropogenic sources (soot/PAHs from combustion sources). As shown in the SOM (Fig. S17), the total aerosol particle distribution $\mathrm{d} N_{\mathrm{T}} / \mathrm{d} \log D_{\mathrm{a}}$ observed during exemplary period $\# 1$ exhibits a much higher peak at the same diameter, and the ratio between $\mathrm{d} N_{\mathrm{F}} / \mathrm{d} \log D_{\mathrm{a}}$ and $\mathrm{d} N_{\mathrm{T}} / \mathrm{d} \log D_{\mathrm{a}}$ at $D_{\mathrm{a}}=0.7 \mu \mathrm{m}$ is similar to the near-constant proportion of fluorescent submicron particles observed throughout the campaign $(\sim 0.1 \%$, Fig. S5). Accordingly, we do not consider this and other submicron peaks in $\mathrm{d} N_{\mathrm{F}} / \mathrm{d} \log D_{\mathrm{a}}$ as characteristic for FBAP and exclude them from all further analysis and discussion. With regard to the FBAP peak observed at $D_{\mathrm{a}} \approx 3 \mu \mathrm{m}$, period \#1 provides a relatively narrow example (nearly monodisperse with $\sigma_{\mathrm{g}} \sim 1.2$ ) that may consist of particles from the same or similar sources (e.g., spores from similar types of fungi). In many other cases we observed broader peaks that seemed to comprise two or more types of FBAPs with slightly different diameters (Figs. S18-S19) or overlapped with other characteristic modes that are like to have originated from different sources and biological species.

Figure 7c-d (exemplary period \#2) illustrate another frequently observed FBAP size distribution pattern, with a broad peak centered at $\sim 3 \mu \mathrm{m}$ and a smaller peak at $\sim 1.5 \mu \mathrm{m}$. Periods \#1 and \#2 both exemplify situations where the observed FBAP size distribution was fairly stable over the course of $\sim 12 \mathrm{~h}$, as opposed to events where short-term 

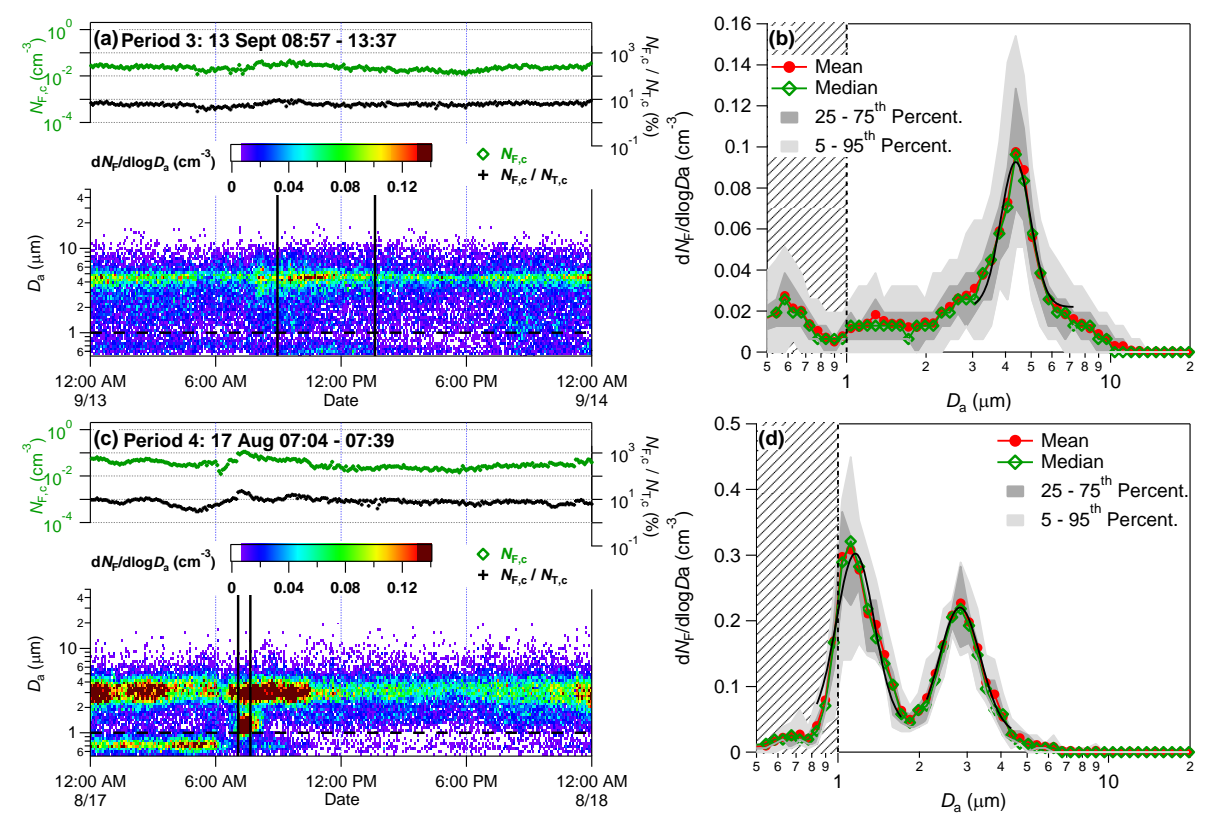

Fig. 8. Characteristic FBAP number size distribution patterns observed during exemplary periods \#3 and \#4 (plots analogous to Fig. 7). (a)-(b) Period \#3; Fit 3.1: $D_{\mathrm{a}}=3.0-7.2 \mu \mathrm{m} ; D_{\mathrm{a}, \mathrm{g}}=4.4 \mu \mathrm{m}, \sigma_{\mathrm{g}}=1.14, N=1.0 \times 10^{-2} \mathrm{~cm}^{-3}$; (c)-(d) Period \#4; Fit 4.1: $D_{\mathrm{a}}=0.84-1.7 \mu \mathrm{m}$; $D_{\mathrm{a}, \mathrm{g}}=1.2 \mu \mathrm{m}, \sigma_{\mathrm{g}}=1.18, N=4.0 \times 10^{-2} \mathrm{~cm}^{-3}$; Fit 4.2: $D_{\mathrm{a}}=2.1-4.4 \mu \mathrm{m} ; D_{\mathrm{a}, \mathrm{g}}=2.8 \mu \mathrm{m}, \sigma_{\mathrm{g}}=1.19, N=2.8 \times 10^{-2} \mathrm{~cm}^{-3}$.

bursts of FBAPs extended over only a few minutes or hours (Fig. 8c-d, Fig. S18). Figure 8a-b (exemplary period \#3) illustrate a situation where the FBAP mode around $\sim 5 \mu \mathrm{m}$ was not just overlapping with, but much more pronounced than the $\sim 3 \mu \mathrm{m}$ mode. In this case the peak near $5 \mu \mathrm{m}$ is exceptionally narrow, suggesting particles from the same or similar sources as discussed above. In most other cases, the peaks around $\sim 5 \mu \mathrm{m}$ were broader (Fig. S18) and likely composed of particles from a variety of different sources. Figure 8c-d (exemplary period $\# 4$ ) illustrate a situation where a narrow peak at $\sim 1.1 \mu \mathrm{m}$ dominates the FBAP size distribution. This pattern was uniquely observed over a $35 \mathrm{~min}$ period on 17 August. The small particle size and the short duration suggest that the $\sim 1.1 \mu \mathrm{m}$ peak consisted of single bacterial cells from a nearby source. It occurred in parallel to a narrow peak at $\sim 3 \mu \mathrm{m}$, but the temporal evolution of the two peaks was very different. The peak at $\sim 3 \mu \mathrm{m}$ was present before and persisted beyond the short-term burst of the one-micron-sized FBAPs.

Figure 9a-d (exemplary periods \#5 and \#6) show FBAP size distributions with a distinct and narrow peak at $\sim 13 \mu \mathrm{m}$ that appeared on 10 October and persisted until 29 October. Most likely the $\sim 13 \mu \mathrm{m}$ peak is due to pollen grains from a nearby tree $(<20 \mathrm{~m}$ away) that was blossoming during this exceptionally warm period in October 2006. In the relevant size range $(12-17 \mu \mathrm{m})$, the FBAP peak (pollen grains) also dominated the total aerosol particle concentration and size distribution with FBAP/TAP ratios in the range of 60$100 \%$ (25-75th percentile, mean $73 \%$ ). Figure 9 also shows that the size resolution and sensitivity of the UV-APS are sufficient for separating and quantifying different types of FBAPs independent of the varying concentrations of TAP (and non-biological fluorescent particles $<1 \mu \mathrm{m}$ ). Supplemental Fig. S20a-d show that FBAP peaks around $\sim 1.5 \mu \mathrm{m}$, $\sim 3 \mu \mathrm{m}$ and $\sim 5 \mu \mathrm{m}$ were often detectable even during periods of very low aerosol concentration levels.

\subsubsection{Average size distributions}

The number and mass size distributions for both TAPs and FBAPs averaged over the whole campaign are shown in Fig. 10. The TAP number size distribution $\mathrm{d} N_{\mathrm{T}} / \mathrm{d} \log D_{\mathrm{a}}$ was generally dominated by a peak at the lower end of the investigated size range ( $D_{\mathrm{a}} \approx 0.7 \mu \mathrm{m}$, Fig. 10a; monthly averages in Fig. S21). Note that this "peak" is likely due to a steep decrease in the UV-APS detection efficiency for small particles at $D_{\mathrm{a}}<0.7 \mu \mathrm{m}$; otherwise the distribution would likely increase to the lowest size bin and peak at a size below that which the UV-APS can detect. Supplemental Fig. S22 shows the campaign mean $N_{\mathrm{T}} / \mathrm{d} \log D_{\mathrm{a}}$ size distribution with a $\log$ arithmic $y$-axis in order to resolve characteristic features at the low values of $\mathrm{d} N_{\mathrm{T}} / \mathrm{d} \log D_{\mathrm{a}}$ observed at large diameters. For example, a shoulder at $\sim 3 \mu \mathrm{m}$ can be attributed to the corresponding FBAP peak in $N_{\mathrm{F}} / \operatorname{d} \log D_{\mathrm{a}}$.

The campaign and monthly average size distributions of fluorescent aerosol particles, $\mathrm{d} N_{\mathrm{F}} / \mathrm{d} \log D_{\mathrm{a}}$, are shown in Fig. 10c and Fig. 11a-d, respectively. The submicron peak at $D_{\mathrm{a}} \approx 0.7 \mu \mathrm{m}$ generally coincided with the peak in $N_{\mathrm{T}} / \mathrm{d} \log D_{\mathrm{a}}$ 

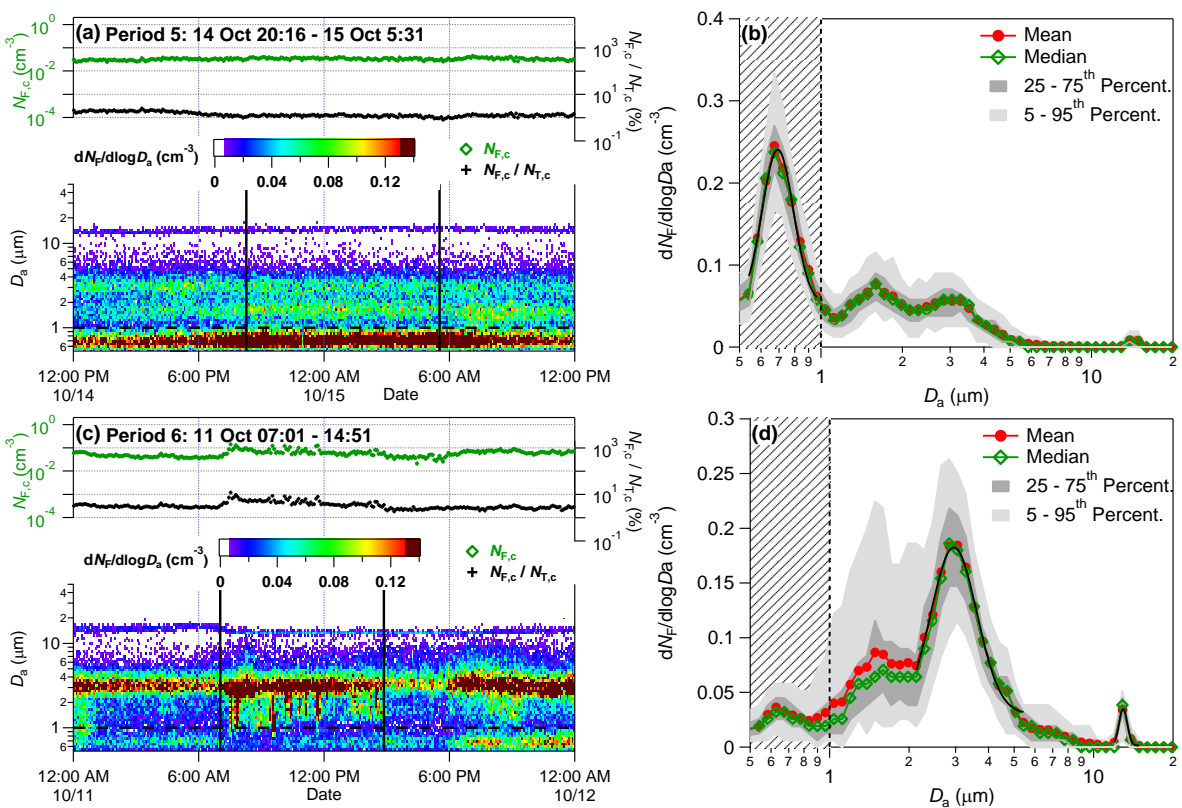

Fig. 9. Characteristic FBAP number size distribution patterns observed during exemplary periods \#5 and \#6 (plots analogous to Fig. 7). (a)-(b) Period \#5; Fit 5.1: $D_{\mathrm{a}}=0.54-0.96 \mu \mathrm{m} ; D_{\mathrm{a}, \mathrm{g}}=0.74 \mu \mathrm{m}, \sigma_{\mathrm{g}}=1.14, N=2.7 \times 10^{-1} \mathrm{~cm}^{-3}$; (c)-(d) Period \#6; Fit 6.1: $D_{\mathrm{a}}=2.1-5.4 \mu \mathrm{m}$; $D_{\mathrm{a}, \mathrm{g}}=3.0 \mu \mathrm{m}, \sigma_{\mathrm{g}}=1.22, N=3.3 \times 10^{-2} \mathrm{~cm}^{-3}$; Fit 6.2: $D_{\mathrm{a}}=12.0-14.9 \mu \mathrm{m} ; D_{\mathrm{a}, \mathrm{g}}=13.0 \mu \mathrm{m}, \sigma_{\mathrm{g}}=1.04, N=1.30 \times 10^{-3} \mathrm{~cm}^{-3}$.
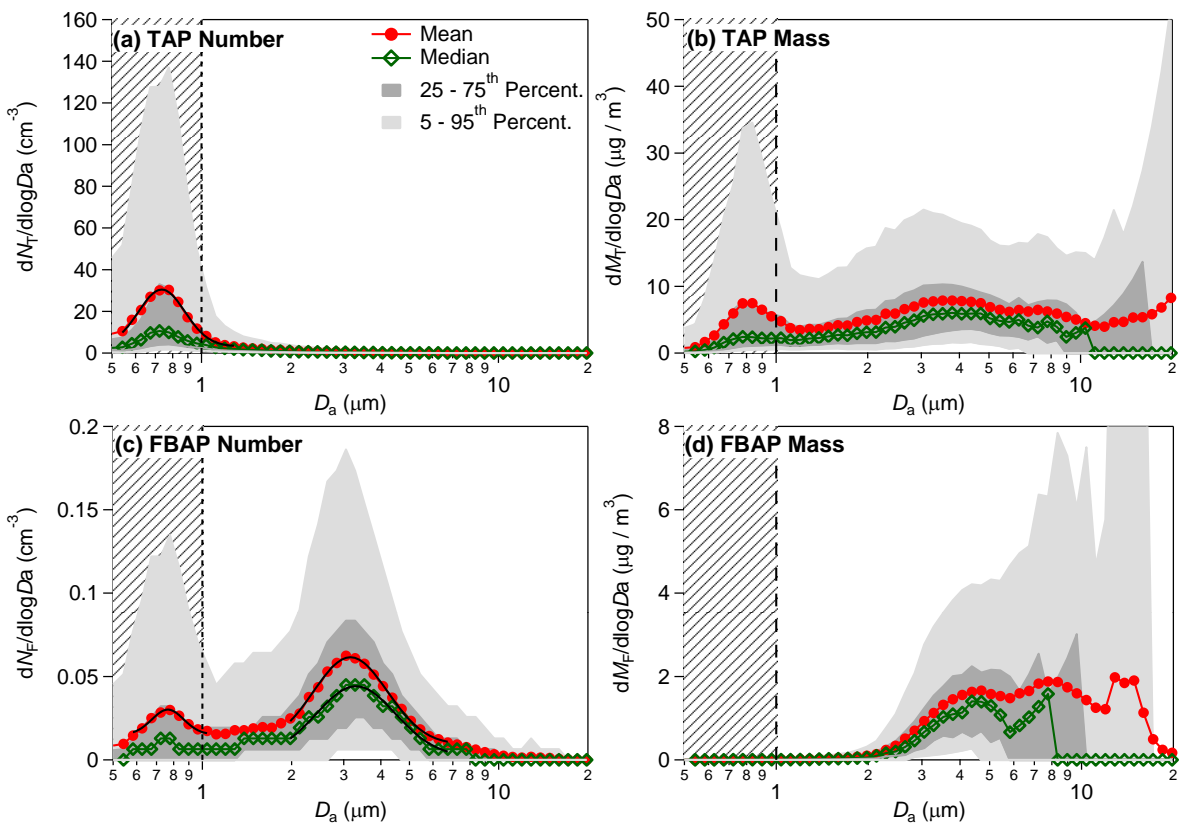

Fig. 10. Average particle number and mass size distributions for the entire measurement period. Red traces represent mean values, green traces represent median values, dark gray regions show 25-75th percentile range, and light gray regions show 5-95th percentile range. Hatched area below $1.0 \mu \mathrm{m}$ indicates particle size range where fluorescent particles were not considered FBAP due to interference with non-biological aerosol. Black traces are lognormal fits to individual peaks with the following fit parameters: (a) TAP number $\left(\mathrm{d} N_{\mathrm{T}} / \mathrm{d} \log D_{\mathrm{a}}\right)$ : Fit $N_{\mathrm{T}}-1: D_{\mathrm{a}}=0.54-1.3 \mu \mathrm{m} ; D_{\mathrm{a}, \mathrm{g}}=0.74 \mu \mathrm{m}, \sigma_{\mathrm{g}}=1.20, N=5.3 \mathrm{~cm}^{-3}$, (b) TAP Mass $\left(\mathrm{d} M_{\mathrm{T}} / \mathrm{d} \log D_{\mathrm{a}}\right) ;(\mathbf{c})$ FBAP Number $\left(\mathrm{d} N_{\mathrm{F}} / \mathrm{d} l o g D_{\mathrm{a}}\right) ;$ Fit $N_{\mathrm{F}}-1$ (mean): $D_{\mathrm{a}}=0.58-1.0 \mu \mathrm{m} ; D_{\mathrm{a}, \mathrm{g}}=0.76 \mu \mathrm{m}, \sigma_{\mathrm{g}}=1.13, N=2.0 \times 10^{-3} \mathrm{~cm}^{-3}$; Fit $N_{F}-2$ (mean): $D_{\mathrm{a}}=2.0-6.7 \mu \mathrm{m} ; D_{\mathrm{a}, \mathrm{g}}=3.2 \mu \mathrm{m}, \sigma_{\mathrm{g}}=1.33$, $N=1.6 \times 10^{-2} \mathrm{~cm}^{-3}$, Fit $N_{\mathrm{F}}-3$ (median): $D_{\mathrm{a}}=2.0-6.7 \mu \mathrm{m} ; D_{\mathrm{a}, \mathrm{g}}=3.3 \mu \mathrm{m}, \sigma_{\mathrm{g}}=1.36, N=1.4 \times 10^{-2} \mathrm{~cm}^{-3}$; (d) FBAP Mass: d $M_{\mathrm{F}} / \mathrm{dlog} D_{\mathrm{a}}$. 

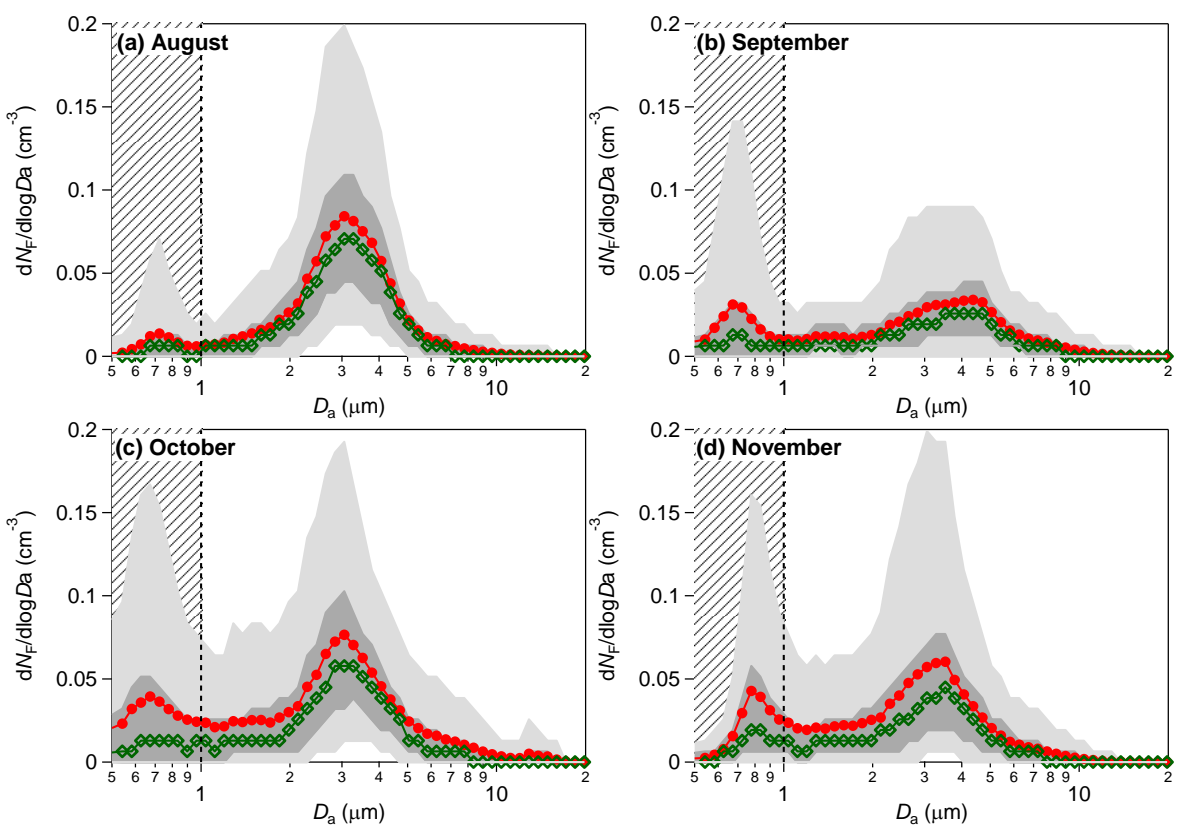

Fig. 11. Average FBAP number size distributions for each month of the measurement period (plots analogous to Fig. 10): (a) August, (b) September, (c) October, (d) November.

and is not considered characteristic for biological particles, as discussed above. The campaign average size distribution was dominated by an FBAP peak at $\sim 3 \mu \mathrm{m}$, and in the monthly averaged size distributions of August and October this peak was even narrower and more intense. In the monthly averaged size distributions of September and November, however, the peak was substantially broader and the maximum was shifted towards higher $D_{\mathrm{a}}$, indicating the presence of different and more diverse types of FBAP. A small mode at $\sim 1.5 \mu \mathrm{m}$ is present in the mean FBAP distribution as well as in each monthly plot. Lastly, an FBAP mode at $\sim 13 \mu \mathrm{m}$ can be seen in the mean FBAP number distribution. As discussed previously, this mode was small in number concentration, but was almost completely comprised of FBAP material.

The size distributions of TAP mass were much broader than those weighted by number and also differed in the fact that they exhibited several more distinct local maxima. The campaign mean TAP mass distributions (Fig. 10b) looked generally similar to each of the constituent months (Fig. S23) with a distinct peak at $0.8 \mu \mathrm{m}$, a broad peak with two local maxima centered between 3-8 $\mu \mathrm{m}$, and an upward slope at particle diameters above $\sim 12 \mu \mathrm{m}$. During August, September and November the same four peaks were observed in the TAP mass distribution as in the campaign mean. In October an additional peak at $13.8 \mu \mathrm{m}$ was also observed, showing what are likely pollen particles observed during the month of October and of high enough relative abundance to contribute noticeably to the month-average TAP mass distribution. The highest concentration at each of the two dominant
TAP mass peaks were in November, when the monthly mean was 0.36 and $0.31 \mu \mathrm{g} \mathrm{m}^{-3}$ for the 0.84 and $3.05 \mu \mathrm{m}$ peaks, respectively.

The campaign mean FBAP mass distribution (Fig. 10d) was generally bimodal, with broad peaks centered at 4.4 and $7.8 \mu \mathrm{m}$. A sharper peak centered at $13.8 \mu \mathrm{m}$ came from the October-specific pollen particles, not as clearly evident in any other month (Fig. S24). The August mean FBAP mass distribution (Fig. S24a) also shows a small shoulder at $13.8 \mu \mathrm{m}$, indicating that the source of the October particle peak may have additional sources located farther from the sampling inlet and occurring at different times. These may be related to other pollen-producing plants that were releasing FBAPs earlier in the summer. Many pollen types have average grain sizes larger than the upper size cut-off of the UV-APS, however. So, while the instrument may be able to detect some pollens efficiently, it is not well suited as a total pollen detector. Unlike the TAP mass distributions, the FBAP mass distributions showed consistently negative slopes at the highest particle diameter channels, indicating the large particles shown in the TAP mass distribution originated from some mechanical process that did not also produce particles containing measurable concentrations of biological material. In general, the size distributions of FBAP mass were shifted to larger particle sizes in September and October as compared with August and November. 


\subsubsection{Ratio of fluorescent bioparticles to total particles}

Taking a ratio of the number of FBAPs $\left(\mathrm{d} N_{\mathrm{F}}\right)$ and TAPs $\left(\mathrm{d} N_{\mathrm{T}}\right)$ in each size bin allows the determination of the relative contribution of biological particles at each particle size. As discussed previously, the density of each particle was assumed to have a value of unity. This determines that the value of the $\mathrm{d} N_{\mathrm{F}} / \mathrm{d} N_{\mathrm{T}}$ ratio is equal to $\mathrm{d} M_{\mathrm{F}} / \mathrm{d} M_{\mathrm{T}}$ by definition, though this is not the case for integrated $N_{\mathrm{F}} / N_{\mathrm{T}}$ and $M_{\mathrm{F}} / M_{\mathrm{T}}$ values. For observed particles of diameter less than $2.5 \mu \mathrm{m}$, the $\mathrm{d} N_{\mathrm{F}} / \mathrm{d} N_{\mathrm{T}}$ ratio was less than $10 \%$ for an average of the entire measurement period (Fig. 12) and for each individually-averaged month (Fig. S25), indicating that relatively few of these small particles were FBAPs. Mean ratio curves show two local maxima, consistently located at similar particle diameters of 3.8-4.7 $\mu \mathrm{m}$ and $9.0-10.4 \mu \mathrm{m}$, respectively. The peaks are more distinct in the August and September averages, while for October and November the mean ratio curves appear closer to being a broad single peak between 3 and $12 \mu \mathrm{m}$. The first clear peak in the $\mathrm{d} N_{\mathrm{F}} / \mathrm{d} N_{\mathrm{T}}$ distribution remained relatively constant in size during the measurement period $(4.4-4.7 \mu \mathrm{m})$ and monthly mean values show that the peak represented a range of $23-32 \%$ FBAP material. The second peak in the $\mathrm{d} N_{\mathrm{F}} / \mathrm{d} N_{\mathrm{T}}$ distribution that can be clearly seen in each of the four months showed slightly more FBAP material: August $(38 \%, 10.4 \mu \mathrm{m})$, September $(34 \%, 9.0 \mu \mathrm{m})$, and November $(31 \%, 9.6 \mu \mathrm{m})$. The October peak at $\sim 10 \mu \mathrm{m}$ was obscured by an additional large peak at $\sim 13 \mu \mathrm{m}$ and was therefore more difficult to quantitatively determine. This $\sim 3$ week-long particle event produced a relatively sharp peak at $12.9 \mu \mathrm{m}$ in the October average, with $62 \%$ of the particles as being FBAPs. A period from 6-7 August also shows a high percentage ( $>60 \%$ ) of FBAP at $D_{\mathrm{a}} 11-15 \mu \mathrm{m}$, indicating that, while the large particle peak in October was the most pronounced, other periods also indicate FBAPs in this size range. The counting statistics, as discussed in the previous section, are poor for the detection of large particles $(>\sim 8 \mu \mathrm{m})$, and therefore median values often reflect the fact that particle of this size were often not present in $>50 \%$ of the sampled $5 \mathrm{~L}$ volumes. The mean (red) curve, therefore, best represents the $\mathrm{d} N_{\mathrm{F}} / \mathrm{d} N_{\mathrm{T}}$ ratios at the upper particle sizes. Further example of this is that the light gray shaded area between the 5th and 95th percentile curves covers the entire ratio from $0-100 \%$ at all particle diameters greater than $\sim 7 \mu \mathrm{m}$ and that the median value goes to zero at $\sim 10 \mu \mathrm{m}$ for each month.

The ratio of the size distributions averaged over the entire measurement campaign (Fig. 12) show similar trends to each of the individual months. Three local maxima are apparent, at aerodynamic particle diameters of 4.70, 9.65, and $13.8 \mu \mathrm{m}$. Even though the particles of diameter greater than $13 \mu \mathrm{m}$ were almost exclusively present only within the month of October, the month's large peak at these sizes heavily influences the 4-month average (Fig. 10a). As a way of removing the very local point source during October, the average

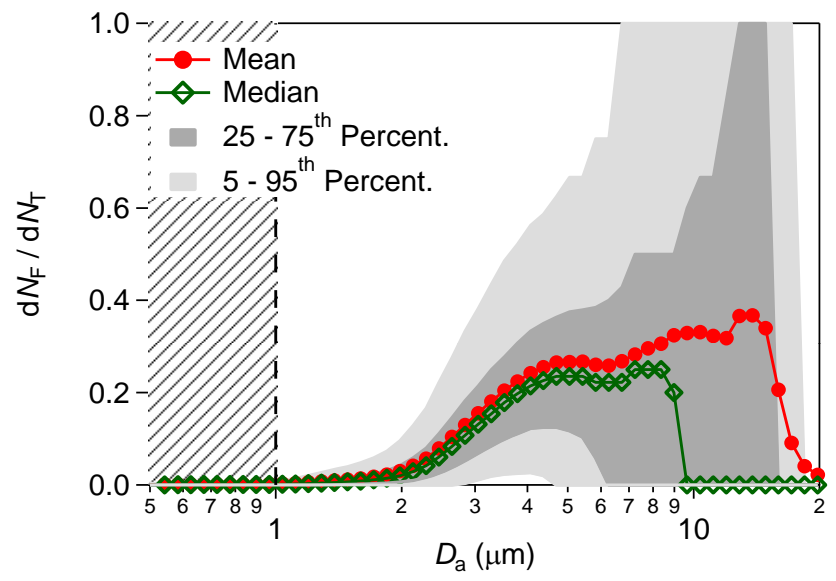

Fig. 12. Average size distribution of the FBAP to TAP number concentration ratio $\left(\mathrm{d} N_{\mathrm{F}} / \mathrm{d} N_{\mathrm{T}}\right)$ for the entire measurement period (plot analogous to Fig. 10).

contribution of FBAP to TAP number and mass over this four-month measurement period was also calculated with the period of 10-29 October removed. The ratio plot is shown in Fig. S26 for comparison, and shows a similar pattern to Fig. 12, but without the sharp peak at $13.8 \mu \mathrm{m}$.

\section{Summary and conclusions}

In this exploratory study we investigated the capability of a UV-APS operated continuously in Mainz, Germany over the 4-month period of August-November 2006 to quantify the concentration and size of FBAPs as an approximate lower limit of biological aerosol particles in semi-urban continental boundary layer air. For this purpose, time series of the integrated coarse particle number and mass concentrations, as well as particle mass and number size distributions of both total particles and fluorescent biological aerosols from the campaign were analyzed. Great variations in coarse particle number and mass concentrations $(1-20 \mu \mathrm{m})$ as well as significant temporal variability of size distributions (using 5-minute measurement points) were observed. Over the course of the measurement period the coarse particle number concentration of FBAPs varied in the range of $1.2 \times 10^{-3}-1.4 \mathrm{~cm}^{-3}$, with an arithmetic mean value of $0.027 \mathrm{~cm}^{-3}\left( \pm 0.026 \mathrm{~cm}^{-3}\right.$, standard deviation). These accounted for $0.09-67 \%$ (mean value $3.9 \% \pm 2.8 \%$ ) of the total coarse particle number concentration. The coarse particle mass concentration of FBAPs varied in the range of $4 \times 10^{-3} \mu \mathrm{g} \mathrm{m}^{-3}$ to $123 \mu \mathrm{g} \mathrm{m}^{-3}$, with an arithmetic mean value of $1.3 \mu \mathrm{g} \mathrm{m}^{-3}\left( \pm 2.0 \mu \mathrm{g} \mathrm{m}^{-3}\right)$. The coarse particle mass of FBAPs accounted for $0.067-92 \%$ (mean value $20 \% \pm 11 \%$ ) of total coarse particle mass concentrations.

The FBAP concentrations reported here fit within the range of bioaerosol concentrations published values within the last decades. Matthias-Maser and Jaenicke report PBAP 
number concentrations of total PM to be $0.6-3.0 \mathrm{~cm}^{-3}(16-$ $20 \%$ ) (2000), and of coarse PM to be $1.9 \mathrm{~cm}^{-3}$ (30\%) (1995). Jaenicke et al. $(2005,2007)$ report $1-3 \mathrm{~cm}^{-3}(3-50 \%$ of coarse PM) in Mainz, Germany and $0.1-1 \mathrm{~cm}^{-3}(15-30 \%)$ in Lake Baikal, Russia and in a related study that $20 \%$ of continental PM (>2 $\mu \mathrm{m})$ and $9 \%$ of marine PM was PBAP (Gruber et al., 1999). Sanchez-Ochoa et al. (2007) report plant matter to have concentrations in various European and N. Atlantic locations to be $0.03-0.36 \mu \mathrm{g} \mathrm{m}^{-3}$, corresponding to $6-22 \%$ of PM mass. Bauer et al. (2002a, b, 2003, 2008) report Austrian fungal spore concentrations of $\sim 2 \times 10^{-2} \mathrm{~cm}^{-3}$ and $2.6 \mu \mathrm{g} \mathrm{m}^{-3}$, corresponding to $40 \%$ of coarse PM $(\sim 2-10 \mu \mathrm{m})(2008), 10 \%$ of coarse Organic Carbon (OC) from cloud water (2002a), and $2.9-5.4 \%$ of the coarse OC (2002b), as well as measured bacteria concentrations of $8 \times 10^{-6} \mathrm{CFU} \mathrm{m}{ }^{-3}$ (colony forming units) (2003). A review by Burrows et al. (2009b) suggests that bacterial concentrations typically exceed $1 \times 10^{-2} \mathrm{~cm}^{-3}$ over land area. Graham et al. (2003) suggest that coarse aerosol from Amazonia was predominantly PBAP, of which fungal spores represented almost all of the $2.3 \times 10^{-1} \mathrm{~cm}^{-3}$ at night and $\sim 90 \%$ of the $2.6 \times 10^{-2} \mathrm{~cm}^{-3}$ during the day. Wiedinmyer et al. (2009) report PBAP to be $40 \%$ of $\mathrm{PM}_{10} \mathrm{OC}$ in high alpine Colorado using off-line fluorescence. And recent studies report $\sim 40 \%$ of coarse particle number above tropical rainforest canopies are FBAP (Gabey et al., 2009; Huffman, Garland, Pöschl et al., 2010). Note, however, that FBAP measurement results from different instruments utilizing laser-induced fluorescence for detection of biological aerosol may differ depending on instrumental design and parameters. Most other bioaerosol measurement techniques are also limited by statistical and systematic uncertainties and will require further validation. Nevertheless, the results obtained with different techniques are largely consistent.

The observed FBAP size distribution from the measurements presented here alternated between periods exhibiting from one to four peaks at particle diameters $>=1 \mu \mathrm{m}$. The temporal variability of peaks in the FBAP size distribution is not surprising in view of the high diversity in type and frequency of occurrence of bacteria and fungal spores detected by microscopy, cultivation and molecular genetic analyses of air particulate matter (Wittmaack et al., 2005; Després et al., 2007; Elbert et al., 2007; Fröhlich-Nowoisky et al., 2009). After experimentally investigating trends in FBAP size distributions, however, the FBAP peaks reported here can be broadly classified into four FBAP modes. The most common mode was observed around $\sim 3 \mu \mathrm{m}$ as the dominant FBAP peak in both number concentration and frequency, consistent with observations by Artaxo and Hansson (1995) who noted a dominant PBAP mode at $\sim 3 \mu \mathrm{m}$ in samples collected in the Amazon Basin, Brazil. An average of the UV-APS study in Mainz shows a strong diel cycle to the $\sim 3 \mu \mathrm{m}$ peak with a maximum in the mid-morning at $\sim 07: 00$ after the sun came up and a constant background throughout the rest of the day. This mode is likely due to fungal spores, whose mechanism for release may be some combination of elevated relative humidity and sunlight. This general pattern is consistent with a morning peak in total fungal spore and bacteria concentrations as recently measured in an urban area of Egypt (AbdelHameed et al., 2009). The additional FBAP modes observed over the four months of measurements can be grouped around $\sim 1.5 \mu \mathrm{m}, \sim 5 \mu \mathrm{m}$, and $\sim 13 \mu \mathrm{m}$. The smallest mode was likely caused by individual bacterial cells or agglomerates and was most often observed at $\sim 1.5 \mu \mathrm{m}$, though the peak of this mode varied between $1.1-1.8 \mu \mathrm{m}$. The $\sim 5 \mu \mathrm{m}$ mode encompasses a variety of peaks observed at different times, though rarely was it seen as a monodisperse peak or set of peaks. Peaks in this region were most often broad and not lognormally distributed, but often distinct from the $3 \mu \mathrm{m}$ peak. The least frequent of the commonly observed mode was a $\sim 13 \mu \mathrm{m}$ peak observed for three weeks in October. Though the peak exhibited low absolute concentration $\left(<2 \times 10^{-3} \mathrm{~cm}^{-3}\right)$, the relative fraction of FBAP to TAP during this period and size range averaged $73 \%$ and often ranged to $100 \%$. These particles were very likely pollen grains released from a nearby blossoming tree. Lognormal fits of selected FBAP peaks were performed in order to provide estimates of characteristic PBAP modes for inputs for aerosol models. The observations that the relative fraction of FBAP to TAP was highest at large sizes is consistent with observations by Kenny and Jennings (1998) that the fraction of biological particles in marine aerosol was highest at $\sim 3-18 \mu \mathrm{m}$. Provided that FBAP can be regarded as a proxy for viable PBAP, the observed size distributions also suggest that the number concentration of viable bioparticles is dominated by fungal spores of agglomerated bacteria $(\sim 3 \mu \mathrm{m})$, rather than single bacterial cells $(\sim 1 \mu \mathrm{m})$.

The results of this exploratory study highlight both the usefulness of FBAP measurements from the UV-APS and similar instruments and the need for further work. Carefully monitoring or controlling UV excitation and detection parameters (e.g. laser intensity) over time and between different identical instruments will be helpful in determining measurement reproducibility and will be discussed in future studies. By integrating only fluorescence channels three and above, and by removing particles sizes below $1 \mu \mathrm{m}$, a conservative approach was used in this study to avoid determination of non-biological aerosol as FBAP, thus suggesting the concentration and size distributions reported can be regarded as an approximate lower limit for actual PBAP abundances. Additional future work will also be to compare UV-APS measurements with other real-time FBAP detectors, culturability and DNA-based techniques, as well as fluorescence and electron microscopy analysis of co-collected samples. We propose and intend to pursue such studies to advance the development of FBAP measurement techniques and the knowledge of the abundance and properties of PBAP in the atmosphere. 
Table A1. List of frequently used acronyms and symbols.

\begin{tabular}{|c|c|c|}
\hline Acronym/Symbol & Unit & Description \\
\hline PBAP & & primary biological aerosol particle \\
\hline FBAP & & fluorescent biological aerosol particle \\
\hline FAP & & fluorescent aerosol particle \\
\hline NAP & & non-fluorescent aerosol particle \\
\hline TAP & & total aerosol particle (including fluorescent and non-fluorescent) \\
\hline$N$ & $\mathrm{~cm}^{-3}$ & particle number concentration \\
\hline$N_{\mathrm{F}}$ & $\mathrm{cm}^{-3}$ & $N$ of fluorescent particles (fluorescence bins $>3$ ) \\
\hline$N_{\mathrm{F}, \mathrm{c}}$ & $\mathrm{cm}^{-3}$ & $\begin{array}{l}N \text { of coarse fluorescent particles }\left(D_{\mathrm{a}, \mathrm{g}} 1.037-19.81 \mu \mathrm{m} \text {, size bins } 10-51\right) \text {; } \\
\text { taken as the number concentration of coarse FBAPs }\end{array}$ \\
\hline$N_{\mathrm{T}}$ & $\mathrm{cm}^{-3}$ & $N$ of all particles (TAPs, including fluorescent and non-fluorescent) \\
\hline$N_{\mathrm{T}, \mathrm{c}}$ & $\mathrm{cm}^{-3}$ & $N$ of all coarse particles (coarse TAPs, including fluorescent and non-fluorescent) \\
\hline$M$ & $\mu \mathrm{g} \mathrm{m}^{-3}$ & particle mass concentration \\
\hline$M_{\mathrm{F}}$ & $\mu \mathrm{g} \mathrm{m}^{-3}$ & $M$ of fluorescent particles \\
\hline$M_{\mathrm{F}, \mathrm{c}}$ & $\mu \mathrm{g} \mathrm{m}^{-3}$ & $\begin{array}{l}\left.M \text { of coarse fluorescent particles ( } D_{\mathrm{a}, \mathrm{g}} 1.037-19.81 \mu \mathrm{m} \text {, size bins } 10-51\right) \text {; } \\
\text { taken as the number concentration of coarse FBAPs }\end{array}$ \\
\hline$M_{\mathrm{T}}$ & $\mu \mathrm{g} \mathrm{m}^{-3}$ & $M$ of all particles (TAPs, including fluorescent and non-fluorescent) \\
\hline$M_{\mathrm{T}, \mathrm{c}}$ & $\mu \mathrm{g} \mathrm{m}^{-3}$ & $M$ of all coarse particles (coarse TAPs, including fluorescent and non-fluorescent) \\
\hline$D_{\mathrm{a}}$ & $\mu \mathrm{m}$ & aerodynamic particle diameter \\
\hline$D_{\mathrm{a}, \mathrm{g}}$ & $\mu \mathrm{m}$ & geometric mean aerodynamic particle diameter (size bin or lognormal fit) \\
\hline$\sigma_{\mathrm{g}}$ & - & geometric standard deviation of lognormal fit \\
\hline
\end{tabular}

Acknowledgements. J. A. H. and B. T. contributed equally to this work. This work has been supported by the Max Planck Society and LEC-Geocycles Mainz, Germany. The authors gratefully acknowledge support by M. O. Andreae, W. Elbert, V. Després, J. Fröhlich and A. G. Wollny.

The service charges for this open access publication have been covered by the Max Planck Society.

Edited by: J. Thornton

\section{References}

Abdel-Hameed, A. A., Khoder, M. I., Yuosra, S., Osman, A. M., and Ghanem, S.: Diurnal distribution of airborne bacteria and fungi in the atmosphere of Helwan area, Egypt, Sci. Total Environ., 407, 6217-6222, doi:10.1016/j.scitotenv.2009.08.028, 2009.

Agranovski, V., Ristovski, Z., Hargreaves, M., Blackall, P. J., and Morawska, L.: Performance evaluation of the UVAPS: influence of physiological age of airborne bacteria and bacterial stress, J. Aerosol Sci., 34, 1711-1727, doi:10.1016/s00218502(03)00191-5, 2003a.

Agranovski, V., Ristovski, Z., Hargreaves, M., Blackall, P. J., and Morawska, L.: Real-time measurement of bacterial aerosols with the UVAPS: performance evaluation, J. Aerosol Sci., 34, 301317, doi:10.1016/s0021-8502(02)00181-7, 2003b.
Agranovski, V., Ristovski, Z., Blackall, P. J., and Morawska, L.: Size-selective assessment of airborne particles in swine confinement building with the UVAPS, Atmos. Environ., 38, 38933901, doi:10.1016/j.atmosenv.2004.02.058, 2004a.

Agranovski, V., Ristovski, Z. D., Ayoko, G. A., and Morawska, L.: Performance evaluation of the UVAPS in measuring biological aerosols: Fluorescence spectra from NAD(P)H coenzymes and riboflavin, Aerosol Sci. Tech., 38, 354-364, doi:10.1080/02786820490437505, 2004b.

Agranovski, V. and Ristovski, Z. D.: Real-time monitoring of viable bioaerosols: capability of the UVAPS to predict the amount of individual microorganisms in aerosol particles, J. Aerosol Sci., 36, 665-676, doi:10.1016/j.jaerosci.2004.12.005, 2005.

Andreae, M. O.: Aerosols before pollution, Science, 315, 50-51, doi:10.1126/science.1136529, 2007.

Andreae, M. O. and Rosenfeld, D.: Aerosol-cloudprecipitation interactions. Part 1, The nature and sources of cloud-active aerosols, Earth-Sci. Rev., 89, 13-41, doi:10.1016/j.earscirev.2008.03.001, 2008.

Ariya, P. A., Sun, J., Eltouny, N. A., Hudson, E. D., Hayes, C. T., and Kos, G.: Physical and chemical characterization of bioaerosols - Implications for nucleation processes, Int. Rev. Phys. Chem., 28, 1-32, doi:10.1080/01442350802597438, 2009.

Artaxo, P. and Hansson, H. C.: Size Distribution of Biogenic Aerosol - Particles from the Amazon Basin, Atmos. Environ., 29, 393-402, 1995.

Bauer, H., Kasper-Giebl, A., Löflund, M., Giebl, H., Hitzenberger, R., Zibuschka, F., and Puxbaum, H.: The contribution of bacteria 
and fungal spores to the organic carbon content of cloud water, precipitation and aerosols, Atmos. Res., 64, 109-119, 2002a.

Bauer, H., Kasper-Giebl, A., Zibuschka, F., Hitzenberger, R., Kraus, G. F., and Puxbaum, H.: Determination of the carbon content of airborne fungal spores, Anal. Chem., 74, 91-95, doi:10.1021/ac010331+, 2002b.

Bauer, H., Giebl, H., Hitzenberger, R., Kasper-Giebl, A., Reischl, G., Zibuschka, F., and Puxbaum, H.: Airborne bacteria as cloud condensation nuclei, J. Geophys. Res.-Atmos., 108, 4658, doi:10.1029/2003jd003545, 2003.

Bauer, H., Schueller, E., Weinke, G., Berger, A., Hitzenberger, R., Marr, I. L., and Puxbaum, H.: Significant contributions of fungal spores to the organic carbon and to the aerosol mass balance of the urban atmospheric aerosol, Atmos. Environ., 42, 5542-5549, doi:10.1016/j.atmosenv.2008.03.019, 2008.

Bowers, R. M., Lauber, C. L., Wiedinmyer, C., Hamady, M., Hallar, A. G., Fall, R., Knight, R., and Fierer, N.: Characterization of Airborne Microbial Communities at a High-Elevation Site and Their Potential To Act as Atmospheric Ice Nuclei, Appl. Environ. Microb., 75, 5121-5130, doi:10.1128/AEM.00447-09, 2009.

Brosseau, L. M., Vesley, D., Rice, N., Goodell, K., Nellis, M., and Hairston, P.: Differences in detected fluorescence among several bacterial species measured with a direct-reading particle sizer and fluorescence detector, Aerosol Sci. Tech., 32, 545-558, 2000.

Brown, J. K. M. and Hovmoller, M. S.: Epidemiology - Aerial dispersal of pathogens on the global and continental scales and its impact on plant disease, Science, 297, 537-541, 2002.

Bundke, U., Reimann, B., Nillius, B., Jaenicke, R., and Bingemer, H.: Development of a Bioaerosol single particle detector (BIO IN) for the Fast Ice Nucleus CHamber FINCH, Atmos. Meas. Tech., 3, 263-271, 2010,

http://www.atmos-meas-tech.net/3/263/2010/.

Burge, H.: Bioaerosols - Prevalence and Health Effects in the Indoor Environment, J. Allergy Clin. Immun., 86, 687-701, 1990.

Burrows, S. M., Butler, T., Jöckel, P., Tost, H., Kerkweg, A., Pöschl, U., and Lawrence, M. G.: Bacteria in the global atmosphere Part 2: Modeling of emissions and transport between different ecosystems, Atmos. Chem. Phys., 9, 9281-9297, 2009a, http://www.atmos-chem-phys.net/9/9281/2009/.

Burrows, S. M., Elbert, W., Lawrence, M. G., and Pöschl, U.: Bacteria in the global atmosphere - Part 1: Review and synthesis of literature data for different ecosystems, Atmos. Chem. Phys., 9, 9263-9280, 2009,

http://www.atmos-chem-phys.net/9/9263/2009/.

Cabredo, S., Parra, A., and Anzano, J.: Bacteria spectra obtained by laser induced fluorescence, J. Fluoresc., 17, 171-180, doi:10.1007/s10895-007-0155-7, 2007.

Cheng, Y. S., Barr, E. B., Fan, B. J., Hargis, P. J., Rader, D. J., O’Hern, T. J., Torczynski, J. R., Tisone, G. C., Preppernau, B. L., Young, S. A., and Radloff, R. J.: Detection of bioaerosols using multiwavelength UV fluorescence spectroscopy, Aerosol Sci. Tech., 30, 186-201, 1999.

Christner, B. C., Morris, C. E., Foreman, C. M., Cai, R. M., and Sands, D. C.: Ubiquity of biological ice nucleators in snowfall, Science, 319, 1214, doi:10.1126/science.1149757, 2008.

Cox, C. S. and Wathes, C. M.: Bioaerosols handbook, Lewis, Boca Raton, 1995.
Deguillaume, L., Leriche, M., Amato, P., Ariya, P. A., Delort, A.M., Pöschl, U., Chaumerliac, N., Bauer, H., Flossmann, A. I., and Morris, C. E.: Microbiology and atmospheric processes: chemical interactions of primary biological aerosols, Biogeosciences, 5, 1073-1084, 2008,

http://www.biogeosciences.net/5/1073/2008/.

Després, V. R., Nowoisky, J. F., Klose, M., Conrad, R., Andreae, M. O., and Pöschl, U.: Characterization of primary biogenic aerosol particles in urban, rural, and high-alpine air by DNA sequence and restriction fragment analysis of ribosomal RNA genes, Biogeosciences, 4, 1127-1141, 2007, http://www.biogeosciences.net/4/1127/2007/.

Diehl, K., Quick, C., Matthias-Maser, S., Mitra, S. K., and Jaenicke, R.: The ice nucleating ability of pollen - Part I: Laboratory studies in deposition and condensation freezing modes, Atmos. Res., 58, 75-87, 2001.

Dingle, A. N.: Pollens as condensation nuclei, Journal de Recherches Atmospheriques, 2, 231-237, 1966.

Dusek, U., Frank, G. P., Hildebrandt, L., Curtius, J., Schneider, J., Walter, S., Chand, D., Drewnick, F., Hings, S., Jung, D., Borrmann, S., and Andreae, M. O.: Size matters more than chemistry for cloud-nucleating ability of aerosol particles, Science, 312, 1375-1378, doi:10.1126/science.1125261, 2006.

Elbert, W., Taylor, P. E., Andreae, M. O., and Pöschl, U.: Contribution of fungi to primary biogenic aerosols in the atmosphere: wet and dry discharged spores, carbohydrates, and inorganic ions, Atmos. Chem. Phys., 7, 4569-4588, 2007,

http://www.atmos-chem-phys.net/7/4569/2007/.

Eng, J., Lynch, R. M., and Balaban, R. S.: Nicotinamide Adenine Dinucleotide Fluorescence Spectroscopy and Imaging of Isolated Cardiac Myocytes, Biophys. J., 55, 621-630, 1989.

Franze, T., Weller, M. G., Niessner, R., and Pöschl, U.: Protein nitration by polluted air, Environ. Sci. Technol., 39, 1673-1678, doi:10.1021/es0488737, 2005.

Fröhlich-Nowoisky, J., Pickersgill, D. A., Després, V. R., and Pöschl, U.: High diversity of fungi in air particulate matter, P. Natl. Acad. Sci., 106, 12814-12819, doi:10.1073/pnas.0811003106, 2009.

Gabey, A. M., Gallagher, M. W., Whitehead, J., and Dorsey, J.: Measurements of coarse mode and primary biological aerosol transmission through a tropical forest canopy using a dualchannel fluorescence aerosol spectrometer, Atmos. Chem. Phys. Discuss., 9, 18965-18984, 2009,

http://www.atmos-chem-phys-discuss.net/9/18965/2009/.

Garland, R. M., Yang, H., Schmid, O., Rose, D., Nowak, A., Achtert, P., Wiedensohler, A., Takegawa, N., Kita, K., Miyazaki, Y., Kondo, Y., Hu, M., Shao, M., Zeng, L. M., Zhang, Y. H., Andreae, M. O., and Pöschl, U.: Aerosol optical properties in a rural environment near the mega-city Guangzhou, China: implications for regional air pollution, radiative forcing and remote sensing, Atmos. Chem. Phys., 8, 5161-5186, 2008, http://www.atmos-chem-phys.net/8/5161/2008/.

Garland, R. M., Schmid, O., Nowak, A., Achtert, P., Wiedensohler, A., Gunthe, S. S., Takegawa, N., Kita, K., Kondo, Y., Hu, M., Shao, M., Zeng, L. M., Zhu, T., Andreae, M. O., and Pöschl, U.: Aerosol optical properties observed during Campaign of Air Quality Research in Beijing 2006 (CAREBeijing2006): Characteristic differences between the inflow and outflow of Beijing city air, J. Geophys. Res.-Atmos., 114, D00G04, 
doi:10.1029/2008jd010780, 2009.

Graham, B., Guyon, P., Maenhaut, W., Taylor, P. E., Ebert, M., Matthias-Maser, S., Mayol-Bracero, O. L., and Godoi, R. H. M.: Composition and diurnal variability of the natural Amazonian aerosol, J. Geophys. Res., 108, 4765, doi:10.1029/2003JD004049, 2003.

Gregory, P. H.: Distribution of Airborne Pollen and Spores and their Long-Distance Transport, Pure Appl. Geophys., 116, 309-315, 1978.

Gruber, S., Matthias-Maser, S., and Jaenicke, R.: Concentration and Chemical Composition of Aerosol Particles in Marine and Continental Air, J. Aerosol Sci., 30, S9-S10, 1999.

Hairston, P. P., Ho, J., and Quant, F. R.: Design of an instrument for real-time detection of bioaerosols using simultaneous measurement of particle aerodynamic size and intrinsic fluorescence, J. Aerosol Sci., 28, 471-482, 1997.

Hamilton, W. D. and Lenton, T. M.: Spora and Gaia: How microbes fly with their clouds, Ethol. Ecol. Evol., 10, 1-16, 1998.

Harrison, D. E. and Chance, B.: Fluorimetric Technique for Monitoring Changes in Level of Reduced Nicotinamide Nucleotides in Continuous Cultures of Microorganisms, Appl. Microbiol., 19, 446-450, 1970.

Heald, C. L. and Spracklen, D. V.: Atmospheric budget of primary biological aerosol particles from fungal spores, Geophys. Res. Lett., 36, L09806, doi:10.1029/2009g1037493, 2009.

Hill, S. C., Pinnick, R. G., Nachman, P., Chen, G., Chang, R. K., Mayo, M. W., and Fernandez, G. L.: Aerosol-fluorescence spectrum analyzer: real-time measurement of emission spectra of airborne biological particles, Appl. Optics, 34, 7149-7155, 1995.

Ho, J., Spence, M., and Hairston, P.: Measurement of biological aerosol with a fluorescent aerodynamic particle sizer (FLAPS): correlation of optical data with biological data, Aerobiologia, 15, 281-291, 1999

Ho, J.: Future of biological aerosol detection, Anal. Chim. Acta, 457, 125-148, 2002.

Ho, J. and Duncan, S.: Estimating aerosol hazards from an anthrax letter, J. Aerosol Sci., 36, 701-719, doi:10.1016/j.jaerosci.2004.11.019, 2005.

Huber, R., Buchner, M., Li, H. G., Schlieter, M., Speerfeld, A. D., and Riepe, M. W.: Protein binding of NADH on chemical preconditioning, J. Neurochem., 75, 329-335, 2000.

Huffman, J. A., Garland, R. M., Pöschl, U., et al.: Fluorescent biological aerosol particle concentrations and size distributions measured in pristine tropical rainforest air during AMAZE-08, in preparation, 2010.

Iwami, Y., Takahashi-Abbe, S., Takahashi, N., Yamada, T., Kano, N., and Mayanagi, H.: The time-course of acid excretion, levels of fluorescence dependent on cellular nicotinamide adenine nucleotide and glycolytic intermediates of Streptococcus mutans cells exposed and not exposed to air in the presence of glucose and sorbitol, Oral Microbiol. Immun., 16, 34-39, 2001.

Jaenicke, R.: Abundance of cellular material and proteins in the atmosphere, Science, 308, 73, doi:10.1126/science.1106335, 2005.

Jaenicke, R., Matthias-Maser, S., and Gruber, S.: Omnipresence of biological material in the atmosphere, Environ. Chem., 4, 217220, doi:10.1071/en07021, 2007.
Jones, A. M. and Harrison, R. M.: The effects of meteorological factors on atmospheric bioaerosol concentrations - a review, Sci. Total Environ., 326, 151-180, doi:10.1016/j.scitotenv.2003.11.021, 2004.

Jonsson, P., Kullander, F., Vahlberg, C., Jelger, P., Tiihonen, M., Wasterby, P., Tjarnhage, T., and Lindgren, M.: Spectral detection of ultraviolet laser induced fluorescence from individual bioaerosol particles, in: Optically Based Biological and Chemical Detection for Defence III, edited by: Carrano, J. C. and Zukauskas, A., Proceedings of the Society of Photo-Optical Instrumentation Engineers (SPIE), Spie-Int. Soc. Optical Engineering, Bellingham, U83-U94, 2006.

Kanaani, H., Hargreaves, M., Ristovski, Z., and Morawska, L.: Performance assessment of UVAPS: Influence of fungal spore age and air exposure, J. Aerosol Sci., 38, 83-96, doi:10.1016/j.jaerosci.2006.10.003, 2007.

Kanaani, H., Hargreaves, M., Ristovski, Z., and Morawska, L.: Deposition rates of fungal spores in indoor environments, factors effecting them and comparison with non-biological aerosols, Atmos. Environ., 42, 7141-7154, doi:10.1016/j.atmosenv.2008.05.059, 2008a.

Kanaani, H., Hargreaves, M., Smith, J., Ristovski, Z., Agranovski, V., and Morawska, L.: Performance of UVAPS with respect to detection of airborne fungi, J. Aerosol Sci., 39, 175-189, doi:10.1016/j.jaerosci.2007.10.007, 2008b.

Kaye, P. H., Stanley, W. R., Hirst, E., Foot, E. V., Baxter, K. L., and Barrington, S. J.: Single particle multichannel bio-aerosol fluorescence sensor, Opt. Express, 13, 3583-3593, 2005.

Kell, D. B., Ryder, H. M., Kaprelyants, A. S., and Westerhoff, H V.: Quantifying Heterogeneity - Flow Cytometry of Bacterial Cultures, Van Leeuwenhoek, A., Int. J. Gen. Mol. Microbiol., 60, 145-158, 1991.

Kenny, C. M. and Jennings, S. G.: Background bioaerosol measurements at Mace Head, J. Aerosol Sci., 29, S779-S780, doi:10.1016/S0021-8502(98)90572-9, 1998.

Kim, K. Y., Ko, H. J., Kim, H. T., Kim, Y. S., Roh, Y. M., Lee, C. M., and Kim, C. N.: Monitoring of aerial pollutants emitted from swine houses in Korea, Environ. Monit. Assess., 133, 255-266, doi:10.1007/s10661-006-9578-x, 2007.

Lacey, J. and Dutkiewicz, J.: Bioaerosols and Occupational Lung Disease, J. Aerosol Sci., 25, 1371-1404, 1994.

Laflamme, C., Verreault, D., Lavigne, S., Trudel, L., Ho, J., and Duchaine, C.: Autofluorescence as a viability marker for detection of bacterial spores, Front. Biosci., 10, 1647-1653, 2005.

Lavoie, J., Dunkerley, C. J., Kosatsky, T., and Dufresne, A.: Exposure to aerosolized bacteria and fungi among collectors of commercial, mixed residential, recyclable and compostable waste, Sci. Total Environ., 370, 23-28, doi:10.1016/j.scitotenv.2006.05.016, 2006.

Law, A. K. Y., Chau, C. K., and Chan, G. Y. S.: Characteristics of bioaerosol profile in office buildings in Hong Kong, Build. Environ., 36, 527-541, 2001.

Li, J. K., Asali, E. C., and Humphrey, A. E.: Monitoring Cell Concentration and Activity by Multiple Excitation Flourometry, Biotechnol. Progr., 7, 21-27, 1991.

Linskens, H. F. and Cresti, M.: Pollen-allergy as an ecological phenomenon: a review, Plant Biosyst., 134, 341-352, 2000. 
Lohmann, U. and Feichter, J.: Global indirect aerosol effects: a review, Atmos. Chem. Phys., 5, 715-737, 2005, http://www.atmos-chem-phys.net/5/715/2005/.

Manninen, A., Putkiranta, M., Rostedt, A., Saarela, J., Laurila, T., Marjamaki, M., Keskinen, J., and Hernberg, R.: Instrumentation for measuring fluorescence cross sections from airborne microsized particles, Appl. Optics, 47, 110-115, 2008.

Martin, S. T., Andreae, M. O., Artaxo, P., Baumgartner, D., Chen, Q., Goldstein, A. H., Guenther, A., Heald, C. L., MayolBracero, O. L., McMurry, P. H., Pauliquevis, T., Pöschl, U., Prather, K. A., Roberts, G. C., Saleska, S. R., Dias, M. A. S., Spracklen, D. V., Swietlicki, E., and Trebs, I.: Sources and Properties of Amazonian Aerosol Particles, Rev. Geophys., in press, doi:10.1029/2008RG000280, 2010.

Matthias-Maser, S. and Jaenicke, R.: The size distribution of primary biological aerosol particles with radii $>0.2$ mum in an urban rural influenced region, Atmos. Res., 39, 279-286, 1995.

Matthias-Maser, S. and Jaenicke, R.: The size distribution of primary biological aerosol particles in the multiphase atmosphere, Aerobiologia, 16, 207-210, 2000.

McFiggans, G., Artaxo, P., Baltensperger, U., Coe, H., Facchini, M. C., Feingold, G., Fuzzi, S., Gysel, M., Laaksonen, A., Lohmann, U., Mentel, T. F., Murphy, D. M., O’Dowd, C. D., Snider, J. R., and Weingartner, E.: The effect of physical and chemical aerosol properties on warm cloud droplet activation, Atmos. Chem. Phys., 6, 2593-2649, 2006,

http://www.atmos-chem-phys.net/6/2593/2006/.

Morris, C. E., Sands, D. C., Bardin, M., Jaenicke, R., Vogel, B., Leyronas, C., Ariya, P. A., and Psenner, R.: Microbiology and atmospheric processes: an upcoming era of research on biometeorology, Biogeosciences Discuss., 5, 191-212, 2008, http://www.biogeosciences-discuss.net/5/191/2008/.

Mortazavi, R., Hayes, C. T., and Ariya, P. A.: Ice nucleation activity of bacteria isolated from snow compared with organic and inorganic substrates, Environ. Chem., 5, 373-381, doi:10.1071/en08055, 2008.

Moschandreas, D. J., Cha, D. K., and Qian, J.: Measurement of indoor bioaerosol levels by a direct counting method, J. Environ. Eng.-ASCE, 122, 374-378, 1996.

Nikaeen, M., Hatamzadeh, M., Hasanzadeh, A., Sahami, E., and Joodan, I.: Bioaerosol emissions arising during application of municipal solid-waste compost, Aerobiologia, 25, 1-6, doi:10.1007/s10453-008-9102-6, 2009.

Okada, T. and Matsunum, K.: Determination of particle-size distribution and concentration of cigarette-smoke by a light-scattering method, J. Colloid Interf. Sci., 48, 461-469, 1974.

Pan, Y. L., Holler, S., Chang, R. K., Hill, S. C., Pinnick, R. G., Niles, S., Bottiger, J. R., and Bronk, B. V.: Real-time detection and characterization of individual flowing airborne biological particles: fluorescence spectra and elastic scattering measurements, P. Soc. Photo-Ot. Ins., 3855, 117-125, 1999.

Pan, Y. L., Pinnick, R. G., Hill, S. C., Rosen, J. M., and Chang, R. K.: Single-particle laser-induced-fluorescence spectra of biological and other organic-carbon aerosols in the atmosphere: Measurements at New Haven, Connecticut, and Las Cruces, New Mexico, J. Geophys. Res.-Atmos., 112(15), D24s19, doi:10.1029/2007jd008741, 2007.
Pan, Y. L., Pinnick, R. G., Hill, S. C., and Chang, R. K.: Particle-Fluorescence Spectrometer for Real-Time SingleParticle Measurements of Atmospheric Organic Carbon and Biological Aerosol, Environ. Sci. Technol., 43, 429-434, doi:10.1021/es801544y, 2009.

Pinnick, R. G., Hill, S. C., Nachman, P., Pendleton, J. D., Fernandez, G. L., Mayo, M. W., and Bruno, J. G.: Fluorescence Particle Counter for Detecting Airborne Bacteria and Other Biological Particles, Aerosol Sci. Tech., 23, 653-664, 1995.

Pinnick, R. G., Hill, S. C., Pan, Y. L., and Chang, R. K.: Fluorescence spectra of atmospheric aerosol at Adelphi, Maryland, USA: measurement and classification of single particles containing organic carbon, Atmos. Environ., 38, 1657-1672, doi:10.1016/j.atmosenv.2003.11.017, 2004.

Pöschl, U.: Atmospheric aerosols: Composition, transformation, climate and health effects, Angew. Chem. Int. Edit., 44, 7520 7540, doi:10.1002/anie.200501122, 2005.

Pöschl, U., Sinha, B. W., Martin, S. T., et al.: Biogenic nuclei for clouds and precipitation over the Amazonian rainforest, in preparation, 2010.

Pratt, K. A., DeMott, P. J., French, J. R., Wang, Z., Westphal, D. L., Heymsfield, A. J., Twohy, C. H., Prenni, A. J., and Prather, K. A.: In situ detection of biological particles in cloud ice-crystals, Nat. Geosci., 2, 397-400, doi:10.1038/ngeo521, 2009.

Prenni, A. J., Petters, M. D., Kreidenweis, S. M., Heald, C. L., Martin, S. T., Artaxo, P., Garland, R. M., Wollny, A. G., and Pöschl, U.: Relative roles of biogenic emissions and Saharan dust as ice nuclei in the Amazon basin, Nat. Geosci., 2, 401-404, doi:10.1038/ngeo517, 2009.

Reyes, F. L., Jeys, T. H., Newbury, N. R., Primmerman, C. A., Rowe, G. S., and Sanchez, A.: Bio-aerosol fluorescence sensor, Field Anal. Chem. Tech., 3, 240-248, 1999.

Rosenfeld, D., Lohmann, U., Raga, G. B., O’Dowd, C. D., Kulmala, M., Fuzzi, S., Reissell, A., and Andreae, M. O.: Flood or drought: How do aerosols affect precipitation?, Science, 321, 1309-1313, doi:10.1126/science.1160606, 2008.

Sanchez-Ochoa, A., Kasper-Giebl, A., Puxbaum, H., Gelencser, A., Legrand, M., and Pio, C.: Concentration of atmospheric cellulose: A proxy for plant debris across a west-east transect over Europe, J. Geophys. Res.-Atmos., 112, D23s08, doi:10.1029/2006jd008180, 2007.

Schnell, R. C. and Vali, G.: Atmospheric Ice Nuclei from Decomposing Vegetation, Nature, 236, 163-165, 1972.

Seaver, M., Eversole, J. D., Hardgrove, J. J., Cary, W. K., and Roselle, D. C.: Size and fluorescence measurements for field detection of biological aerosols, Aerosol Sci. Tech., 30, 174-185, 1999.

Seedorf, J.: An emission inventory of livestock-related bioaerosols for Lower Saxony, Germany, Atmos. Environ., 38, 6565-6581, doi:10.1016/j.atmosenv.2004.08.023, 2004.

Setlow, B. and Setlow, P.: Levels of Oxidized and Reduced Pyridine Nucleotides in Dormant Spores and During Growth, Sporulation, and Spore Germination of Bacillus megaterium, J. Bacteriol., 129, 857-865, 1977.

Simoneit, B. R. T. and Mazurek, M. A.: Organic Matter of the Troposphere - II. Natural Background of Biogenic Lipid Matter in Aerosols Over the Rural Western United States, Atmos. Environ., 16, 2139-2159, 1982. 
Sivaprakasam, V., Huston, A. L., Scotto, C., and Eversole, J. D.: Multiple UV wavelength excitation and fluorescence of bioaerosols, Opt. Express, 12, 4457-4466, 2004.

Sivaprakasam, V., Pletcher, T., Tucker, J. E., Huston, A. L., McGinn, J., Keller, D., and Eversole, J. D.: Classification and selective collection of individual aerosol particles using laserinduced fluorescence, Appl. Optics, 48, B126-B136, 2009.

Snyder, A. P., Maswadeh, W. M., Tripathi, A., Eversole, J., Ho, J., and Spence, M.: Orthogonal analysis of mass and spectral based technologies for the field detection of bioaerosols, Anal. Chim. Acta, 513, 365-377, doi:10.1016/j.aca.2004.03.003, 2004.
Sun, J. M. and Ariya, P. A.: Atmospheric organic and bio-aerosols as cloud condensation nuclei (CCN): A review, Atmos. Environ., 40, 795-820, doi:10.1016/j.atmosenv.2005.05.052, 2006.

Wiedinmyer, C., Bowers, R. M., Fierer, N., Horanyi, E., Hannigan, M., Hallar, A. G., McCubbin, I., and Baustian, K.: The contribution of biological particles to observed particulate organic carbon at a remote high altitude site, Atmos. Environ., 43, 4278-4282, doi:10.1016/j.atmosenv.2009.06.012, 2009.

Wittmaack, K., Wehnes, H., Heinzmann, U., and Agerer, R.: An overview on bioaerosols viewed by scanning electron microscopy, Sci. Total Environ., 346, 244-255, doi:10.1016/j.scitotenv.2004.11.009, 2005. 